\title{
Reforesting severely degraded grassland in the Lesser Himalaya of Nepal: Effects on soil hydraulic conductivity and overland flow production
}

\author{
Chandra Prasad Ghimire, ${ }^{1,2}$ Mike Bonell, ${ }^{3}$ L. Adrian Bruijnzeel, ${ }^{2}$ Neil A. Coles, ${ }^{4}$ \\ and Maciek W. Lubczynski ${ }^{1}$ \\ Received 11 June 2013; revised 24 October 2013; accepted 25 October 2013; published 20 December 2013.
}

[1] Severely degraded hillslopes in the Lesser Himalaya challenge local communities as a result of the frequent occurrence of overland flow and erosion during the rainy season and water shortages during the dry season. Reforestation is often perceived as an effective way of restoring predisturbance hydrological conditions but heavy usage of reforested land in the region has been shown to hamper full recovery of soil hydraulic properties. This paper investigates the effect of reforestation and forest usage on field-saturated soil hydraulic conductivities $\left(K_{\mathrm{fs}}\right)$ near Dhulikhel, Central Nepal, by comparing degraded pasture, a footpath within the pasture, a 25 year old pine reforestation, and little disturbed natural forest. The hillslope hydrological implications of changes in $K_{\mathrm{fs}}$ with land-cover change were assessed via comparisons with measured rainfall intensities over different durations. High surface and near-surface $K_{\mathrm{fs}}$ in natural forest $\left(82-232 \mathrm{~mm} \mathrm{~h}^{-1}\right.$ ) rule out overland flow occurrence and favor vertical percolation. Conversely, corresponding $K_{\mathrm{fs}}$ for degraded pasture $\left(18-39 \mathrm{~mm} \mathrm{~h}^{-1}\right)$ and footpath $\left(12-26 \mathrm{~mm} \mathrm{~h}^{-1}\right)$ were conducive to overland flow generation during medium- to high-intensity storms and thus to local flash flooding. Pertinently, surface and near-surface $K_{\mathrm{fs}}$ in the heavily used pine forest remained similar to those for degraded pasture. Estimated monsoonal overland flow totals for degraded pasture, pine forest, and natural forest were $21.3 \%, 15.5 \%$, and $2.5 \%$ of incident rainfall, respectively, reflecting the relative ranking of surface $K_{\mathrm{fs}}$. Along with high water use by the pines, this lack of recovery of soil hydraulic properties under pine reforestation is shown to be a critical factor in the regionally observed decline in base flows following large-scale planting of pines and has important implications for regional forest management.

Citation: Ghimire, C. P., M. Bonell, L. A. Bruijnzeel, N. A. Coles, and M. W. Lubczynski (2013), Reforesting severely degraded grassland in the Lesser Himalaya of Nepal: Effects on soil hydraulic conductivity and overland flow production, J. Geophys. Res. Earth Surf., 118, 2528-2545, doi:10.1002/2013JF002888.

\section{Introduction}

[2] The forests of the Himalaya provide a number of vital environmental functions, both to the people living in the area itself and those in the neighboring alluvial plains [Ives and Messerli, 1989; Singh, 2007; Joshi and Negi, 2011]. In the past, environmental scientists expressed serious concern

\footnotetext{
${ }^{1}$ Faculty of Geo-Information Science and Earth Observation, University of Twente, Enschede, The Netherlands.

${ }^{2}$ Critical Zone Hydrology Group, Faculty of Earth and Life Sciences, VU University, Amsterdam, Netherlands.

${ }^{3}$ The Centre for Water Law, Water Policy and Science under the auspices of UNESCO, The UNESCO IHP-HELP Centre, University of Dundee, Dundee, UK

${ }^{4}$ Centre for Excellence in Ecohydrology, University of Western Australia, Perth, Western Australia, Australia.

Corresponding author: C. P. Ghimire, Faculty of Geo-Information Science and Earth Observation, University of Twente, PO Box 217, Enschede, 7500 AE, Netherlands. (c_ghimire@yahoo.com)

C2013. American Geophysical Union. All Rights Reserved. 2169-9003/13/10.1002/2013JF002888
}

about the rapid deterioration of the Himalayan environment. Until comparatively recently, it was widely assumed that deforestation and overgrazing in the Himalaya were primarily responsible for the large-scale flooding and sedimentation experienced in the plains of northern India and Bangladesh [e.g., Eckholm, 1976; Nautiyal and Babor, 1985; Myers, 1986]. While this view is no longer tenable in the light of subsequent scientific evidence demonstrating the comparatively limited influence of land use on these large-scale hydrological phenomena [Bruijnzeel and Bremmer, 1989; Ives and Messerli, 1989; Hofer, 1993; cf. Gardner and Gerrard, 2003; Hofer and Messerli, 2006], the local adverse hydrological effects of advanced land degradation, such as accelerated erosion, enhanced peak discharges, and reduced dry season flows [Bartarya, 1989; Bruijnzeel and Bremmer, 1989] required remedial action [Tiwari, 1995; Negi et al., 1998]. At the same time, the continued provision of various goods traditionally supplied by forests to rural communities as part of their subsistence economy-such as timber and fuelwood, fodder, litter for animal bedding and composting, as well as a host of other minor products [Mahat et al., 1987; 
GHIMIRE ET AL.: REFORESTATION AND HILLSLOPE $K_{\mathrm{fs}}$

Singh and Singh, 1992; Singh and Sundriyal, 2009; Joshi and Negi, 2011]_-had to be taken into account as well [Campbell and Mahat, 1975]. Thus, as part of a major effort to reforest severely degraded pastures and shrublands in the Middle Mountains of Central Nepal [Shepherd and Griffin, 1984], some 23,000 ha were planted to fast-growing coniferous species (mainly Pinus roxburghii and P. patula at an initial planting density of $\sim 1600$ trees $\mathrm{ha}^{-1}$ ) between 1980 and 2000 (District Forest Offices, Kabhre and Sindhupalchok, Nepal, unpublished data, 2010). In addition, on-farm tree planting and natural regrowth on abandoned fields increased during this period as well [Gilmour and Nurse, 1991; Paudel et al., 2012] such that a recent survey reported a marked increase in both forest area and quality across Nepal's Middle Mountains over the last two decades [HURDEC Nepal and Hobley, 2012]. Nevertheless, and as also reported for other parts of the world [Trimble et al., 1987; Waterloo et al., 2000; Jackson et al., 2005; Scott et al., 2005], local farmers in Central Nepal have expressed concerns about diminishing streamflow volumes following the large-scale planting of the pines [República, 2012]. Consequently, understanding the role of reforestation in regulating the flows of water in this complex and fragile environment is critical, even more so in view of the area's strongly seasonal climate (approximately $80 \%$ of the annual rainfall is received between June and September) [Merz, 2004; Ghimire et al., 2012]. The pressure on the area's water resources is immense [Merz et al., 2003; Schreier et al., 2006] and is expected to increase markedly in the future due to a combination of climate change and socioeconomic developments [Mishra and Herath, 2011; Bandhyopadhyay, 2013].

[3] Hillslope soil hydraulic conductivity, in combination with prevailing rainfall intensities, has been shown to affect volumes of storm runoff generation, rates of surface erosion, and dry season flows in many tropical and subtropical uplands, including the Himalayas [e.g., Gilmour et al., 1987; Bruijnzeel and Bremmer, 1989; Gardner and Gerrard, 2002, 2003; Ziegler et al., 2004a, 2004b; Zimmermann and Elsenbeer, 2009; Bonell et al., 2010; Krishnaswamy et al., 2012; Ghimire et al., 2013; Krishnaswamy et al., 2013]. Therefore, restoring diminished soil hydraulic conductivities to help recover the replenishment of soil moisture and groundwater reserves and concurrently curtailing the high volumes of infiltration-excess overland flow (IOF) typically associated with advanced land degradation [e.g., Gilmour et al., 1987; Chandler and Walter, 1998; Zhou et al., 2002; Gerrard and Gardner, 2002; Cuo et al., 2008; Ghimire et al., 2013] are perceived by many in the Himalayan region to be the most effective path toward boosting diminished dry season flows and reducing flood-related hazards [cf. Bartarya, 1989; Negi et al., 1998; Tambe et al., 2012]. However, there is a dearth of quantitative information about the extent to which, and under what circumstances, reforestation in the heavily populated Middle Mountains [cf. Singh et al., 1984; Hrabovsky and Miyan, 1987] can indeed restore diminished soil hydraulic conductivities given the continued pressure on the forests (both remaining natural forests and newly planted stands) [Singh and Sundriyal, 2009; Joshi and Negi, 2011]. Gilmour et al. [1987] were among the first to present field-saturated soil hydraulic conductivity $\left(K_{\mathrm{fs}}\right)$ data for top- and subsoils under various land-cover types in the Chautara area of Central Nepal. They observed a trend of increasing surface $K_{\mathrm{fs}}$ with age for 5 to 12 year old pine plantations compared to a very degraded pasture, although values were still much lower than the $K_{\mathrm{fs}}$ associated with largely undisturbed natural forest. However, subsequent remeasurement at the same sites after more than 25 years [Ghimire et al., 2013] showed dramatic reductions in surface $K_{\mathrm{fs}}$ in both the planted and natural forests in comparison to those of Gilmour et al. [1987]. A reduction in soil biological activity and macropore formation due to overintensive usage of the forests was identified as the chief causal factor for this finding [Ghimire et al., 2013]. Unfortunately, there is reason to believe that despite the optimistic notion regarding the overall improved quality of the Lesser Himalayan forests expressed by HURDEC and Hobley [2012], the situation of over-intensive usage of forests and correspondingly poor soil hydrological functioning as described by Ghimire et al. [2013] is not limited to the Chautara area. For example, Gardner and Gerrard [2002] reported very high overland flow occurrence in degraded (broad-leaved) forests in the Likhu Khola catchment north of Kathmandu, whereas Tiwari et al. [2009] and Wester [2013] recently presented similar evidence for community-managed forests farther west in Nepal.

[4] As part of a larger venture investigating the "trade-off" between the higher water use of tree plantations (relative to pasture) on the one hand and possibly improved infiltration opportunities through organic matter buildup during plantation maturation on the other hand [cf. Bruijnzeel, 1989; Krishnaswamy et al., 2012; Krishnaswamy et al., 2013], this study aims to extend the work of Gilmour et al. [1987] and Ghimire et al. [2013] at a new location (the Jikhu Khola Catchment near Dhulikhel). Apart from presenting extensive new $K_{\mathrm{fs}}$ data for heavily degraded pasture, little disturbed broad-leaved forest and an intensively used pine plantation, and extending the range of measurements to the hillslope scale, this paper includes the first measurements of $K_{\mathrm{fs}}$ for a heavily frequented rural footpath in the Himalaya. With the aid of statistical analysis, $K_{\mathrm{fs}}$ values for the respective landcover types are compared and combined with locally measured rainfall intensities of various temporal resolutions to infer the associated changes in the dominant hillslope stormflow pathways (as defined in Chappell et al. [2007]). The latter, in turn, are compared against measured overland flow totals generated on the pasture and in the two contrasting forest types to verify the inferred processes of stormflow generation. In doing so, particular attention is paid to an evaluation of the impacts of reforesting the former degraded pasture and the sustained intensive use of the pine stand. Finally, the implications of the present findings on overland flow generation and infiltration for the evolution of regional dry season flows are discussed in terms of the trade-off hypothesis referred to above. To this end, the new overland flow data are combined with recent information on forest and pasture water use in the area [Baral, 2012].

\section{Study Area}

[5] The field measurements were conducted between 1500 and $1620 \mathrm{~m}$ above mean sea level (a.m.s.l.) in the Jikhu Khola Catchment (JKC) $\left(27^{\circ} 35^{\prime}-27^{\circ} 41^{\prime} \mathrm{N}\right.$; 85 $\left.32^{\prime}-85^{\circ} 41^{\prime} \mathrm{E}\right)$ close to Dhulikhel (the District Headquarters of Kabhre district) in the Middle Mountains of Central Nepal (Figure 1). The region has a complex geology that has resulted in equally complex spatial patterns of topography, soils, and vegetation. 
GHIMIRE ET AL.: REFORESTATION AND HILLSLOPE $K_{\mathrm{fs}}$

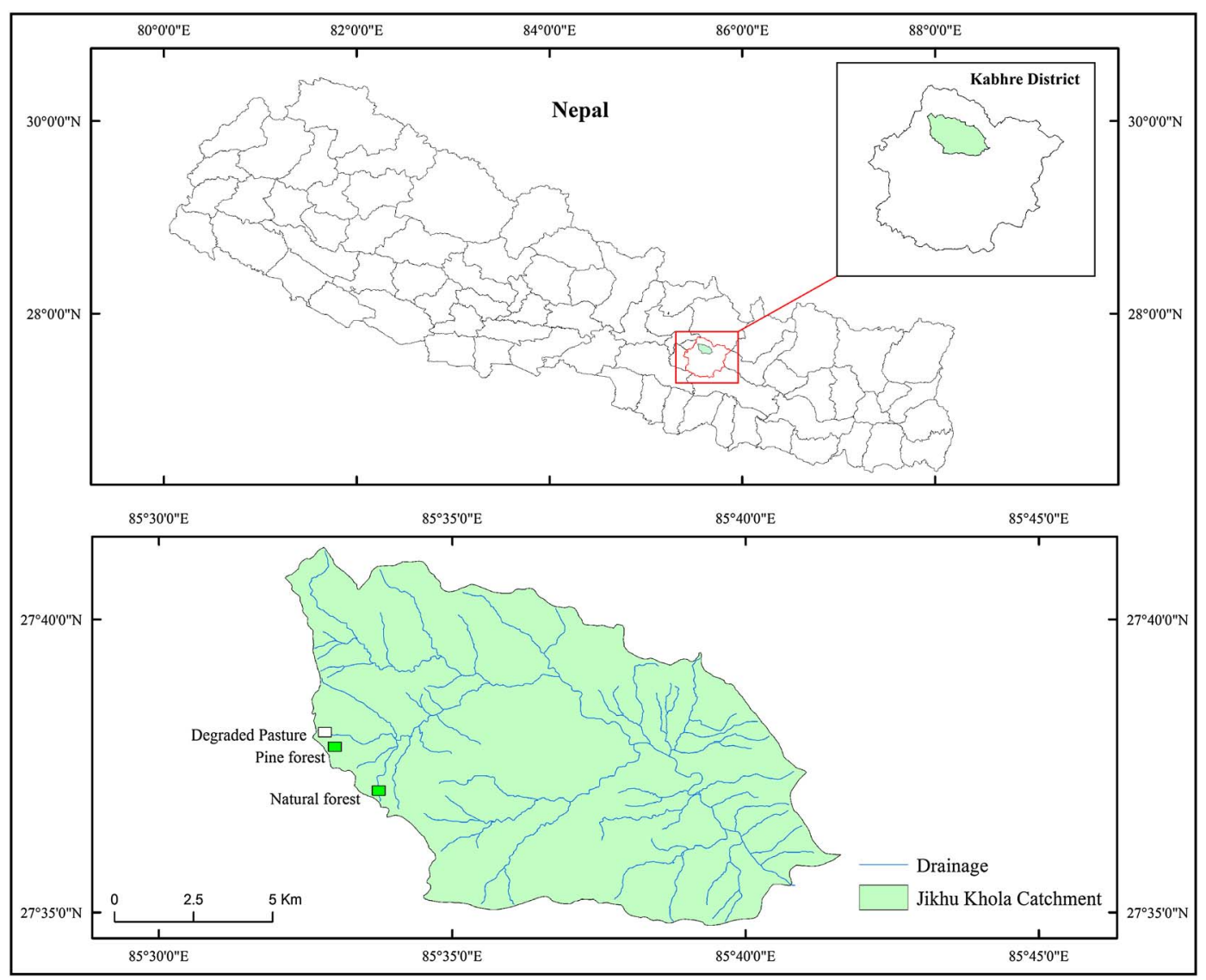

Figure 1. Location of the study sites in the Jikhu Khola Catchment in the Middle Mountains of Central Nepal.

The geology includes phyllites, schists, and quartzites on which Cambisols and Luvisols of silty to clay loam textures have developed [Maharjan, 1991]. The climate of the JKC is largely humid subtropical, grading to warm temperate above $2000 \mathrm{~m}$ a.m.s.l. Mean $( \pm \mathrm{SD})$ annual rainfall, as measured at mid-elevation (1560 m a.m.s.l.) for the period 1993-1998, was $1487( \pm 157) \mathrm{mm}[$ Merz, 2004]. Similar amounts were recorded at $1580 \mathrm{~m}$ a.m.s.l. between October 2010 and September 2011 by Ghimire et al. [2012]. Annual reference evaporation [following Allen et al., 1998] for the period 1993-2000 was $1170 \mathrm{~mm}$ [Merz, 2004]. The main seasons are, respectively, the monsoon (June to September), the post monsoon period (October to November), winter (December to February), and the premonsoon period (March to May). The rainy season brings about $80 \%$ of the total annual precipitation. In general, July is the wettest month with about $27 \%$ of the annual rainfall. The driest months are November to February, each accounting for about $1 \%$ of the annual rainfall [Merz, 2004]. The vegetation at elevations between 1000 and $2000 \mathrm{~m}$ a.m.s.l. consists of a largely evergreen mixed broadleaved forest dominated by Schima wallichii and various chestnuts and oaks (Castanopsis spp., Quercus spp.), with admixtures of Rhododendron arboreum above $1500 \mathrm{~m}$ a.m.s.l. Due to the prevailing population pressure, much of the original species-rich forest has disappeared, with most of the remaining forest either occurring on slopes that are too steep for agricultural activity or being in various stages of degradation because of continued disturbance [Dobremez, 1976].
Vegetation cover in the catchment consists of $30 \%$ forest (both natural and planted), $7 \%$ shrubland, and $6 \%$ grassland, with the remaining 57\% largely under agriculture [Merz, 2004]. Parts of the catchment were deforested more than a century ago [Mahat et al., 1986]. The JKC was subjected to active reforestation with various pines (notably $P$. roxburghii and $P$. patula) until 2004 as part of the Nepal-Australia Forestry Project. According to local farmers, several springs have dried up completely and the yields of others have been declining since the reforestation [República, 2012].

[6] The respective measuring sites were selected so as to represent the various stages of anthropogenic pressure, ranging from a heavily compacted footpath through degraded pasture and an intensively used pine reforestation, to little disturbed natural broad-leaved forest. All sites were located within the headwater area of the JKC on slopes ranging from $20^{\circ}$ to $25^{\circ}$. The land use at the respective research sites can be characterized as follows:

[7] 1. Degraded pasture: This site (southeast exposure, overall slope angle $18^{\circ}$ ) has been heavily grazed for more than 150 years (based on various personal communications). Numerous patches of compacted or bare soil surface are evident (Figure 2a). The dominant grass and herb species are Imperata cylindrica, Saccharum spontaneum, and Ajuga macrosperma. Little or no grass cover remains at the peak of the dry season (March-May). The numerous heavily compacted footpaths distributed along and across the hillslope have been in use for more than a century. In summary, 


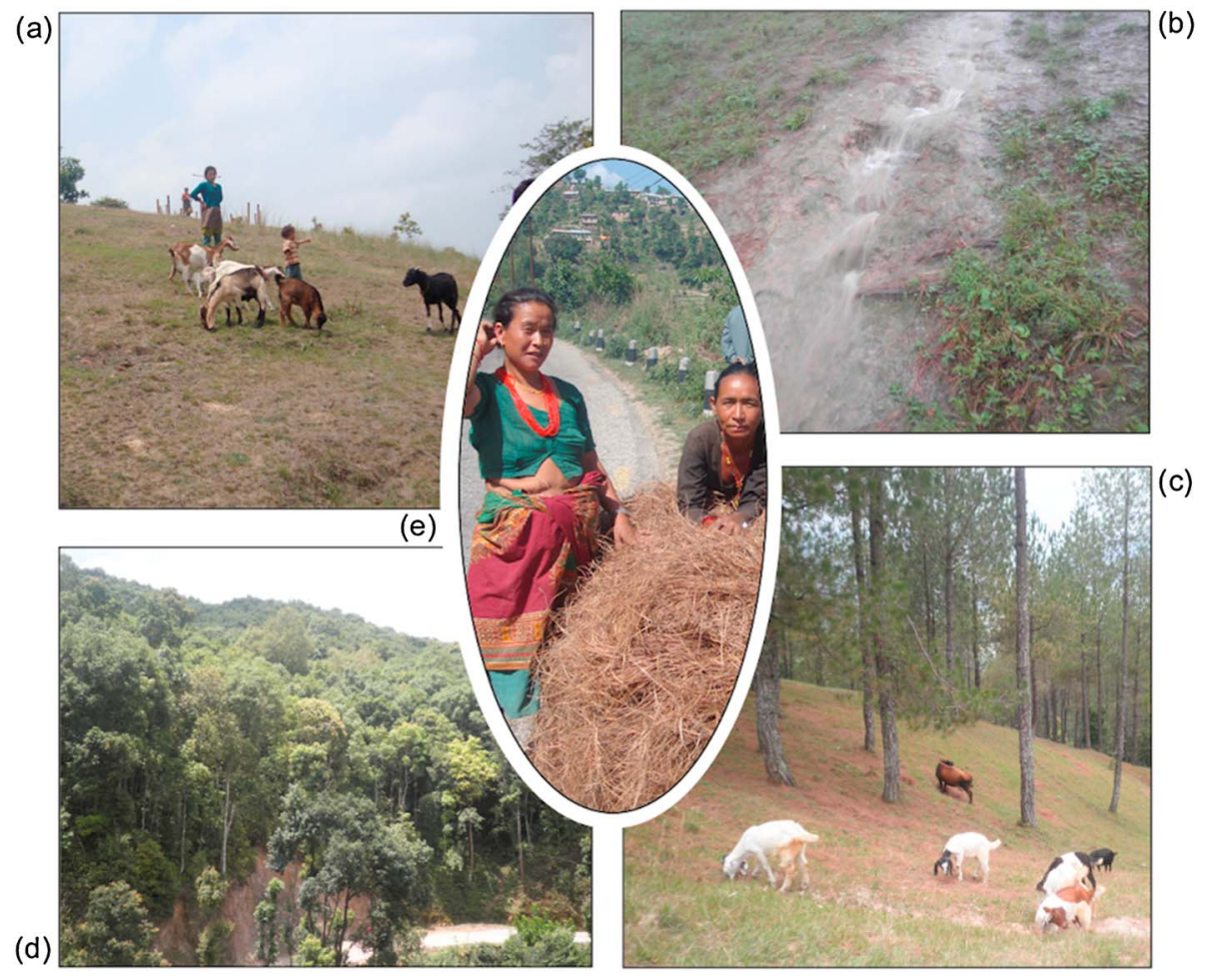

Figure 2. (a) Cattle grazing at the degraded pasture site, (b) infiltration-excess overland flow on footpath during a medium-intensity rainfall event, (c) cattle grazing at the pine forest site, (d) little disturbed natural forest site, and (e) local women with litter material collected from the pine forest site.

the measurements at this site are considered to represent the combined effect of more than 150 years of continuous cattle grazing in addition to human trampling pressure.

[8] 2. Footpath: A heavily compacted footpath running along the slope within the degraded pasture that had been in use for more than 150 years. No vegetation existed on the heavily trampled surface (Figure 2b). Local people are using the footpath for two purposes mainly: (a) to access a pine forest close to the degraded pasture, and (b) to reach a small viewing tower located just above the degraded pasture which is a point of attraction for locals and tourists alike. On average, about 30 people pass this footpath twice a day.

[9] 3. Pine forest: This former degraded pasture located approximately $400 \mathrm{~m}$ from the studied degraded pasture on a $20^{\circ}$ slope of southwest exposure (Figure 1) was planted with $P$. roxburghii in 1986. At the time of the $K_{\mathrm{fs}}$ measurements (2011), the trees were 25 years old. An understory was largely absent as grazing by cattle is common (Figure $2 c$ ). In addition, litter is collected for animal bedding while the grassy herb layer is regularly harvested (Figure 2e). Pruning of trees for fuelwood and felling for timber are also common. Combined, these activities have opened up the canopy and compacted the soil surface of the pine forest considerably.

[10] 4. Natural forest: This is a better protected site which consists of dense, largely evergreen forest facing little anthropogenic pressure (Figure $2 \mathrm{~d}$ ). It is located $\sim 2700 \mathrm{~m}$ from the degraded pasture on a $24^{\circ}$ slope of northwest exposure (Figure 1). The tree stratum of the NF consists largely of a mixture of Castanopsis tribuloides and Schima wallichii with a few other minor species [cf. Ghimire et al., 2012]. The soil surface is well covered with a broad-leaved understory as well as a litter layer. Grazing animals and litter collection are excluded, but local people collect mushrooms during the rainy season.

\section{Methods}

\subsection{Field Measurement of $\boldsymbol{K}_{\mathrm{fs}}$}

[11] A disc permeameter [Perroux and White, 1988; McKenzie et al., 2002] was used for the measurement of surface $K_{\mathrm{fs}}$ in the field. Although little is known about the effects of slope on measurements taken by the ponded version of the disc permeameter used here [Casanova, 1998; Joel and Messing, 2000; Bodhinayake et al., 2004], simulations undertaken elsewhere have shown that the effect of slope angles up to $20^{\circ}$ have only a marginal effect on the volume flux and thus on $K_{\mathrm{fs}}$ estimates (K. R. J. Smettem, personal communication, 2012). A steel ring was adapted for use on nonlevel land (slopes $>1^{\circ}$ ). To obtain a uniform emplacement depth while maintaining an adequate water supply head across the soil surface within the ring $(0.27 \mathrm{~m}$ diameter), the lower ring's circumference was cut such that the ring wall was shallower on the upslope side than on the downslope side (i.e., $3 \mathrm{~cm}$ versus $7 \mathrm{~cm}$ height). For the natural forest site where the slope was greater than $20^{\circ}$, the surface $K_{\mathrm{fs}}$ measurements were confined to somewhat flatter microtopographic areas embedded within the overall slope. It is acknowledged that the resulting $K_{\mathrm{fs}}$ estimates may differ from estimates for the steeper slope $\left(>20^{\circ}\right)$. However, given the previously noted fact that slope angles up to $20^{\circ}$ have only a marginal effect on $K_{\mathrm{fs}}$, any such differences were considered to be minimal. Prior to measurement, any straw and stubble present were removed from the surface, with the least amount of surface disturbance. To improve the contact between the 
a)

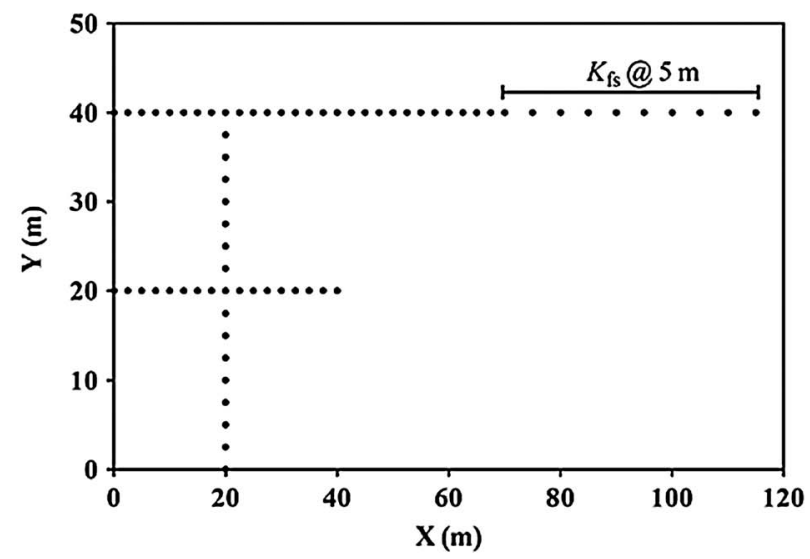

b)

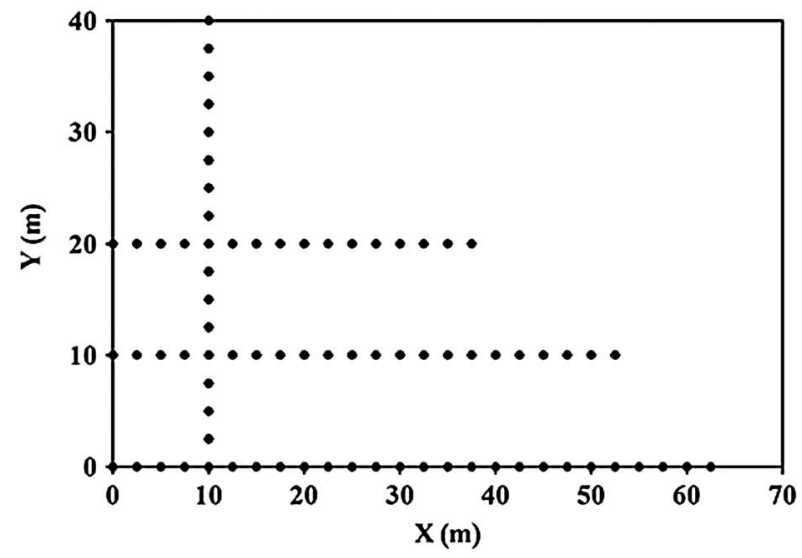

c)

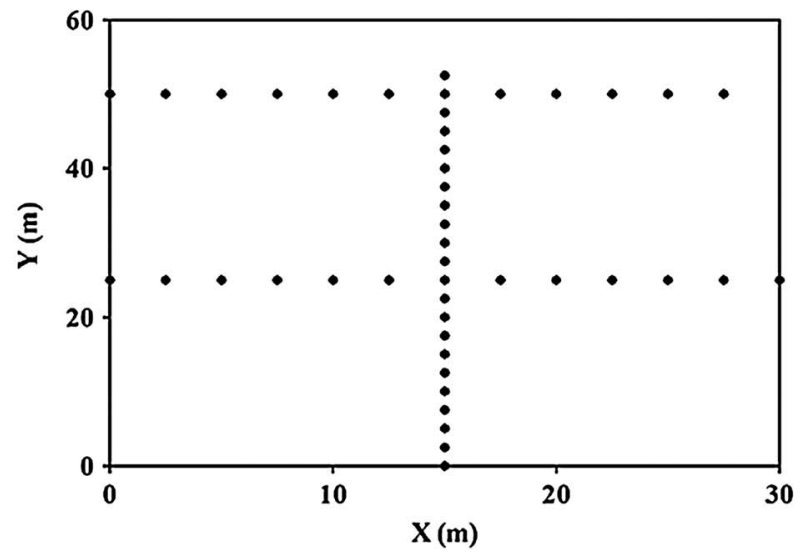

Figure 3. Field-saturated soil hydraulic conductivity sampling grid used at (a) the degraded pasture site, (b) the pine reforestation site, and (c) the natural forest site in the headwaters of the Jikhu Khola catchment, Central Nepal.

permeameter disc and the soil surface, a $5 \mathrm{~mm}$ thick layer of fine sand ( size $<2 \mathrm{~mm}$ ) was placed on the soil surface inside the ring after which the apparatus was placed on the ring. The rates of water discharge through the disc, as inferred from changes in the water levels in the storage tower of the apparatus, were recorded until steady state flow rates were reached. In addition, two soil cores - one before the infiltration measurement commenced and the other after measurement was finished-were taken and weighed in the field. The cores were subsequently transported to the laboratory for the measurement of volumetric soil moisture content (based on gravimetric soil moisture content and dry bulk density). $K_{\mathrm{fs}}\left(\mathrm{mm} \mathrm{h}^{-1}\right)$ was then calculated using the method outlined by McKenzie et al. [2002]:

$$
\mathrm{K}_{f s}=I-\frac{4 b S_{0}^{2}}{\pi r\left(\theta_{0}-\theta_{n}\right)}
$$

where $\theta_{\mathrm{n}}\left(\mathrm{m}^{3} \mathrm{~m}^{-3}\right)$ and $\theta_{\mathrm{o}}\left(\mathrm{m}^{3} \mathrm{~m}^{-3}\right)$ are the in situ volumetric soil moisture contents before and after infiltration, respectively; $b$ is a constant $(0.55) ; S_{\mathrm{o}}\left(\mathrm{mm} \mathrm{h}^{-1 / 2}\right)$, the sorptivity obtained by plotting cumulative infiltration volume versus the square root of time since the start of infiltration; $r$, the radius of the disc permeameter base $(127.5 \mathrm{~mm})$; and $I\left(\mathrm{~mm} \mathrm{~h}^{-1}\right)$, the steady state infiltration rate, calculated as:

$$
I=\frac{q}{\pi r^{2}}
$$

where $q\left(\mathrm{~mm}^{3} \mathrm{~h}^{-1}\right)$ is the slope of the plot of cumulative infiltration versus time after reaching steady state conditions, with $r$ as defined previously.

[12] For the measurement of $K_{\mathrm{fs}}$ in deeper soil layers, a constant-head well permeameter (CHWP) was used [Talsma and Hallam, 1980]. The use of the CHWP was restricted to the dry season to minimize errors from smearing of the auger hole walls [Chappell and Lancaster, 2007]. The experimental procedure involved augering a cylindrical hole (with radius $a=4 \mathrm{~cm}$ ) to the desired depth. Any sealing of pores in the column walls due to the augering was minimized by brushing the walls with a small metal brush. The hole was prewetted for $20 \mathrm{~min}$ before taking the measurement to achieve perimeter saturation as described by Talsma and Hallam [1980]. The CHWP was then inserted to the required depth and the flow measured until a steady state flow rate was reached. $K_{\mathrm{fs}}\left(\mathrm{mm} \mathrm{h}^{-1}\right)$ values were calculated from the measurements using equation (11) of Reynolds et al. [1983]:

$$
\mathrm{K}_{f s}=\frac{C Q_{t}}{2 \pi H^{2}\left[1+\frac{C}{2}\left(\frac{a}{H}\right)^{2}\right]}
$$

Where $Q_{t}\left(\mathrm{~mm}^{3} \mathrm{~h}^{-1}\right)$ is steady state flow rate; $H(\mathrm{~mm})$, the constant height of ponded water in the well; $a(\mathrm{~mm})$, the radius of the well; and $C$, a dimensionless shape factor calculated as:

$$
C=\sinh ^{-1}\left(\frac{H}{a}\right)-\sqrt{\left(\left(\frac{a}{H}\right)^{2}+1\right)}+\frac{a}{H}
$$

\subsection{Experimental Design}

[13] Field-saturated hydraulic conductivity $\left(K_{\mathrm{fs}}\right)$ was measured at the hillslope scale, both at the surface and at depths of $0.05-0.15 \mathrm{~m}, 0.15-0.25 \mathrm{~m}, 0.25-0.50 \mathrm{~m}$, and $0.5-1.0 \mathrm{~m}$. Except in the case of the footpath measurements, the locations of the measurement plots along the respective hillslopes were selected such that the plot's $x$ axis represented the contour line and the $y$ axis the slope (Figure 3 ). Plot size varied from $30 \mathrm{~m} \times 50 \mathrm{~m}$ (natural forest) through $40 \mathrm{~m} \times 65 \mathrm{~m}$ (pine forest) to $40 \mathrm{~m} \times 115 \mathrm{~m}$ (degraded pasture) depending on local slope configuration. Next, several lines of different lengths 
GHIMIRE ET AL.: REFORESTATION AND HILLSLOPE $K_{\mathrm{fs}}$

Table 1. Basic Physical and Chemical Properties of the Soil at Different Depths Under the Studied Contrasting Land Covers in the Headwaters of the Jikhu Khola Catchment, Central Nepal ${ }^{\mathrm{a}}$

\begin{tabular}{|c|c|c|c|c|c|}
\hline Site & Depth (m) & Clay $(\%)$ & Sand $(\%)$ & Silt (\%) & $\mathrm{SOC}(\%)$ \\
\hline \multirow[t]{4}{*}{ Degraded pasture } & $0.05-0.15$ & $19.2( \pm 1.4)$ & $34.0( \pm 3.14)$ & $46.8( \pm 1.77)$ & $2.23( \pm 0.27)$ \\
\hline & $0.15-0.25$ & $16.0( \pm 1.95)$ & $37.2( \pm 3.87)$ & $46.8( \pm 2.46)$ & $0.77( \pm 0.32)$ \\
\hline & $0.25-0.50$ & $14.7( \pm 1.12)$ & $38.5( \pm 1.21)$ & $46.8( \pm 0.22)$ & $0.66( \pm 0.11)$ \\
\hline & $0.50-1.0$ & $12.4( \pm 0.64)$ & $44.1( \pm 1.94)$ & $43.5( \pm 1.40)$ & $0.34( \pm 0.16)$ \\
\hline \multirow[t]{4}{*}{ Pine forest } & $0.05-0.15$ & $19.2( \pm 1.48)$ & $40.0( \pm 2.0)$ & $40.8( \pm 1.08)$ & $1.69( \pm 0.32)$ \\
\hline & $0.15-0.25$ & $17.1( \pm 1.48)$ & $40.5( \pm 0.83)$ & $42.4( \pm 0.99)$ & $0.99( \pm 0.21)$ \\
\hline & $0.25-0.50$ & $14.2( \pm 1.54)$ & $43.0( \pm 1.3)$ & $42.8( \pm 0.94)$ & $0.47( \pm 0.19)$ \\
\hline & $0.50-1.0$ & $11.5( \pm 1.19)$ & $46.7( \pm 4.1)$ & $41.8( \pm 2.99)$ & $0.18( \pm 0.14)$ \\
\hline \multirow[t]{4}{*}{ Natural forest } & $0.05-0.15$ & $29.5( \pm 2.13)$ & $24.0( \pm 1.5)$ & $46.5( \pm 1.33)$ & $4.1( \pm 0.25)$ \\
\hline & $0.15-0.25$ & $29.2( \pm 2.57)$ & $26.3( \pm 1.8)$ & $44.5( \pm 1.69)$ & $1.72( \pm 0.20)$ \\
\hline & $0.25-0.50$ & $28.1( \pm 3.14)$ & $26.1( \pm 1.1)$ & $45.8( \pm 3.0)$ & $1.43( \pm 0.20)$ \\
\hline & $0.50-1.0$ & $26.0( \pm 5.81)$ & $25.7( \pm 2.26)$ & $48.3( \pm 3.78)$ & $0.72( \pm 0.13)$ \\
\hline
\end{tabular}

${ }^{\mathrm{a}}$ Values listed are the means $( \pm \mathrm{SD})$ of six samples.

along and perpendicular to the hillslope were superimposed (Figure 3) to avoid clustering of sampling points in any direction [cf. Ghimire et al., 2013]. Further, at three sites (degraded pasture, pine forest, and natural forest), the subsurface $K_{\mathrm{fs}}$ was measured at $2.5 \mathrm{~m}$ intervals. An exception was made in the upper part of the degraded pasture site where the few measurements were made at $5 \mathrm{~m}$ intervals due to the obstruction caused by the presence of an automatic weather station (see Figure 3). In case of the $70 \mathrm{~m}$ long and $0.4 \mathrm{~m}$ wide footpath, $K_{\mathrm{fs}}$ was measured at $3 \mathrm{~m}$ intervals. For the measurement of surface $K_{\mathrm{fs}}, 6-17$ replications were taken per site via random sampling using a disc permeameter (Table 2). The number of surface $K_{\mathrm{fs}}$ measurements was much less than for the other depths (cf. Table 2) because of the practical limitations of using a disc permeameter on steeply sloping land discussed earlier.

\subsection{Rainfall Intensity}

[14] The rainfall data that were used to infer the dominant hillslope hydrological pathways and changes therein as a function of the level of anthropogenic pressure were recorded at the degraded pasture site during the respective monsoon periods (June-September) of 2010 and 2011.

[15] Rainfall was recorded using a tipping-bucket rain gage (Rain Collector II, Davis Instruments, USA; $0.2 \mathrm{~mm}$ per tip) at 5 min intervals. A rainfall event was defined as having at least $5 \mathrm{~mm}$ of rain in total [Negishi et al., 2006] and was separated from a previous event by a dry period of at least $3 \mathrm{~h}$. The maximum $5 \mathrm{~min}$ rainfall amounts $\left(I_{5 \max }\right.$, expressed as equivalent hourly rainfall intensity) were determined by calculating the maximum precipitation over the corresponding time interval for each event. The maximum $10 \mathrm{~min}$ $\left(I_{10 \max }\right), 15 \mathrm{~min}\left(I_{15 \max }\right), 30 \mathrm{~min}\left(I_{30 \max }\right)$, and $60 \mathrm{~min}$ $\left(I_{60 \max }\right)$ rainfall intensities (all expressed as equivalent hourly rainfall intensities) were derived in a similar manner as well.

\subsection{Overland Flow}

[16] Overland flow at the degraded pasture, pine forest, and natural forest sites was monitored between 20 June and 9 September 2011 (i.e., the bulk of the 2011 rainy season) using a single large $(5 \mathrm{~m} \times 15 \mathrm{~m})$ runoff plot per land-cover type. Runoff was collected in a gutter system funneling the water to a first 1801 collector equipped with a seven-slot divider allowing $1 / 7$ th of the spillover into a second 1801 drum, thereby bringing the total collector capacity to $14401(\sim 20 \mathrm{~mm})$. The water levels in the two collectors were measured continuously using a pressure transducer device (Keller, Germany) placed at the bottom. Collectors were emptied and cleaned after measuring the water level manually every day around 8:45 A.M. local time. Event runoff volume was calculated by converting the water levels to volumes using a calibrated relationship per drum and summing up to obtain total runoff volume. Measured overland flow volumes were corrected for direct rainfall inputs into the runoff collecting system. Overland flow volumes were divided by projected plot area to give overland flow in mm per event. Values were also expressed as the percentage of corresponding rainfall or throughfall (based on Ghimire et al. [2012]) where appropriate.

\subsection{Additional Soil Physical and Chemical Properties}

[17] Additional soil physical and chemical properties such as bulk density, texture, and organic carbon content (SOC) were determined in order to quantify other factors that might affect $K_{\mathrm{fs}}$. Soil bulk density was measured in each plot at randomly selected points (degraded pasture, $n=37$; pine reforestation, $n=18$; natural forest, $n=21$ ) at $0-0.10 \mathrm{~m}$ depth using the core method (196 $\mathrm{cm}^{3}$ cores) [Blake and Hartge, 1986]. The chief soil textural components and SOC were determined at depths of $0.05-0.15 \mathrm{~m}, 0.15-0.25 \mathrm{~m}, 0.25-$ $0.50 \mathrm{~m}$, and $0.50-1.0 \mathrm{~m}$ using a Fritsch particle analyzer [Konert and Vandenberghe, 1997] and the Walkley and Black [1934] procedure, respectively.

\subsection{Data Analysis}

\subsubsection{Inferring the Hydrological Consequences of Different Levels of Anthropogenic Pressure}

[18] When considering hillslope hydrological response to rainfall, the key parameters controlling dominant stormflow pathways are the changes in $K_{\mathrm{fs}}$ with depth in combination with prevailing rainfall intensities [Bonell et al., 1983; Gilmour et al., 1987; Elsenbeer et al., 1999; Ziegler et al., 2006; Zimmermann et al., 2006; Bonell et al., 2010]. To identify a potentially impeding soil layer to different rainfall intensities at each site, selected percentiles of maximum rainfall intensities $I_{\max }$ (e.g., over $5 \mathrm{~min}, I_{5 \max }$ ) as measured at the degraded pasture site were compared with the median $K_{\mathrm{fs}}$ values for each site (i.e., land cover) and depth. The presence of an impeding layer at the surface or at a certain depth for the chosen rainfall intensity is indicated if the latter exceeds 


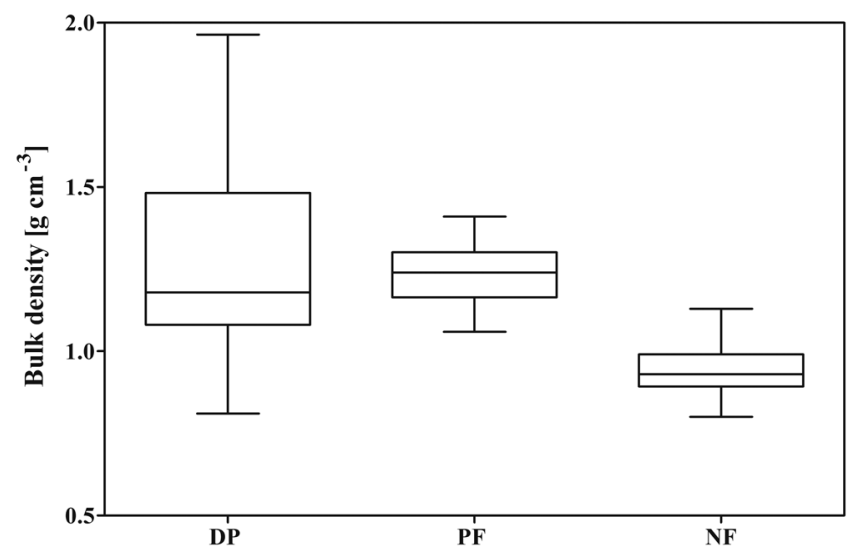

Figure 4. Topsoil $(0-0.10 \mathrm{~m})$ bulk density values at (a) the degraded pasture (DP, $n=37$ ), (b) the pine reforestation (PF, $n=18$ ), and (c) the natural forest (NF, $n=21$ ) site in the headwaters of the Jikhu Khola catchment, Central Nepal.

the median $K_{\mathrm{fs}}$ value under consideration. In turn, dominant pathways of stormflow can then be inferred. Moreover, the disposition of rainfall delivered at the soil surface for the selected maximum rainfall intensity $\left(I_{\max }\right)$ was estimated by comparing that rainfall intensity and $K_{\mathrm{fs}}$.

[19] It is acknowledged that the $K_{\mathrm{fs}}$ data presented in this work represent measurements that are biased toward dry season conditions, and as such, they do not take into account any seasonal variability in $K_{\mathrm{fs}}$. Wet season values of surface $K_{\mathrm{fs}}$ using the disc permeameter in monsoonal southwest India were shown to be reduced by up to an order of magnitude compared to dry season measurements taken over the same locations, possibly due to surface sealing by raindrop impact and blocking of larger pores by sediment carried by overland flow [cf. Bonell et al., 2010; McIntyre, 1958a, 1958b]. Thus, lower $K_{\mathrm{fs}}$ values can be expected during the main monsoon season, and the presently inferred degree and frequency of IOF occurrence may therefore be underestimated at such times. 3.6.2. Statistical Analysis

[20] For all statistical analyses, the language and environment of R, version 2.14.0 [R Development Core Team, 2008] was used. All data sets were tested for normality using the Shapiro-Wilk $W$ statistic [Shapiro and Wilk, 1965]. In the case of non-normal distribution of the data, the raw data were transformed ( $\log _{\mathrm{e}}$ and square root transformations) to achieve a normal or near-normal distribution. However, since it is not possible to compare differently transformed data, it was preferred to use nontransformed data and nonparametric statistical analysis. Differences in $K_{\mathrm{fs}}$ between sites were initially tested using the Kruskal and Wallis [1952] test. If the latter indicated a significant difference between medians, the Mann-Whitney $U$ test with Bonferroni correction was subsequently applied to account for multiple comparisons across sites and specific soil layers. In the case of comparisons between two sites only, differences in $K_{\mathrm{fs}}$ were statistically examined using the MannWhitney $U$ test. Differences in $K_{\mathrm{fs}}$ were assumed to be significant with $p<0.05$ for the Mann-Whitney $U$ test and $p<0.017$ for the Kruskal-Wallis test. For a rapid visual comparison among sites, box plots were computed as well.

3.6.3. Spatial Analysis

[21] To examine the possible effects of spatial correlation length on the above statistical analyses of $K_{\mathrm{fs}}$, the spatial structure of the distribution of this parameter was also analyzed using geostatistics. Where sample sizes were sufficient, new mean and median values for $K_{\mathrm{fs}}$ were calculated by including only every alternate, second or third $K_{\mathrm{fs}}$ value from the original data set, depending on the spatial correlation length. The statistical procedures were then repeated and the results were compared against the full data sets.

[22] The spatial analysis was limited to the degraded pasture, pine forest, and natural forest sites as the number of pairs in the footpath was below 30 (a standard geostatistical rule) [cf. Mohanty and Mousli, 2000]. The sample sizes used in the geostatistical analysis are listed in Table 2. The semivariance $(\gamma)$ was determined according to Matheron [1962]:

$$
\gamma(h)=\frac{1}{2 N(h)}\left\{\sum_{i=1}^{N(h)}\left[Z\left(x_{i}+h\right)-Z\left(x_{i}\right)\right]^{2}\right\}
$$

where $N(h)$ is the number of pairs separated by the lag distance $h$, and $Z\left(x_{\mathrm{i}}\right)$ is the $K_{\mathrm{fs}}$ measured at a point $x_{\mathrm{i}}$. Experimental variograms were also estimated using the language and environment of R. Semivariance was calculated for the residual of square root-transformed (degraded pasture and pine forest sites) and $\log _{\mathrm{e}}$-transformed data (natural forest site) to minimize the effect of outliers. Experimental variograms

Table 2. Descriptive Statistics for Field-Saturated Hydraulic Conductivities $K_{\mathrm{fs}}\left(\mathrm{mm} \mathrm{h}^{-1}\right)$ Associated With Contrasting LandCover Types at Different Depths in the Headwaters of the Jikhu Khola Catchment, Central Nepal

\begin{tabular}{|c|c|c|c|c|c|}
\hline & Surface & $\begin{array}{c}(0.05- \\
0.15 \mathrm{~m})\end{array}$ & $\begin{array}{c}(0.15- \\
0.25 \mathrm{~m})\end{array}$ & $\begin{array}{l}(0.25- \\
0.5 \mathrm{~m})\end{array}$ & $\begin{array}{l}(0.5- \\
1.0 \mathrm{~m})\end{array}$ \\
\hline \multicolumn{6}{|c|}{ Degraded Pasture } \\
\hline Mean & 25 & 41 & 72 & 38 & 19 \\
\hline Median & 18 & 39 & 68 & 35 & 19 \\
\hline $\begin{array}{l}\text { Standard } \\
\text { deviation }\end{array}$ & 20 & 18 & 32 & 16 & 9 \\
\hline Minimum & 4 & 7 & 25 & 14 & 6 \\
\hline Maximum & 70 & 82 & 161 & 96 & 44 \\
\hline Sample size $(n)$ & 17 & $70^{\mathrm{a}}$ & $70^{\mathrm{a}}$ & $70^{\mathrm{a}}$ & $70^{\mathrm{a}}$ \\
\hline \multicolumn{6}{|c|}{ Footpath } \\
\hline Mean & 10 & 24 & 41 & 29 & 16 \\
\hline Median & 12 & 26 & 39 & 30 & 19 \\
\hline $\begin{array}{l}\text { Standard } \\
\text { deviation }\end{array}$ & 5 & 10 & 17 & 10 & 7 \\
\hline Minimum & 4 & 7 & 13 & 14 & 7 \\
\hline Maximum & 18 & 42 & 84 & 53 & 40 \\
\hline Sample size $(n)$ & 7 & 24 & 24 & 24 & 24 \\
\hline \multicolumn{6}{|c|}{ Pine Forest } \\
\hline Mean & 26 & 43 & 109 & 92 & 45 \\
\hline Median & 24 & 39 & 107 & 92 & 45 \\
\hline $\begin{array}{l}\text { Standard } \\
\text { deviation }\end{array}$ & 7 & 19 & 38 & 32 & 11 \\
\hline Minimum & 18 & 11 & 29 & 25 & 24 \\
\hline Maximum & 35 & 125 & 210 & 165 & 69 \\
\hline Sample size $(n)$ & 10 & $80^{\mathrm{a}}$ & $80^{\mathrm{a}}$ & $80^{\mathrm{a}}$ & $80^{\mathrm{a}}$ \\
\hline \multicolumn{6}{|c|}{ Natural Forest } \\
\hline Mean & 333 & 94 & 80 & 51 & 19 \\
\hline Median & 232 & 82 & 64 & 47 & 18.8 \\
\hline $\begin{array}{l}\text { Standard } \\
\text { deviation }\end{array}$ & 356 & 74 & 53 & 29 & 8 \\
\hline Minimum & 32 & 7 & 22 & 11 & 5 \\
\hline Maximum & 1256 & 389 & 285 & 152 & 36 \\
\hline Sample size $(n)$ & 11 & $45^{\mathrm{a}}$ & $45^{\mathrm{a}}$ & $45^{\mathrm{a}}$ & $45^{\mathrm{a}}$ \\
\hline
\end{tabular}

${ }^{a}$ Data used for geostatistical analysis. 
GHIMIRE ET AL.: REFORESTATION AND HILLSLOPE $K_{\mathrm{fs}}$
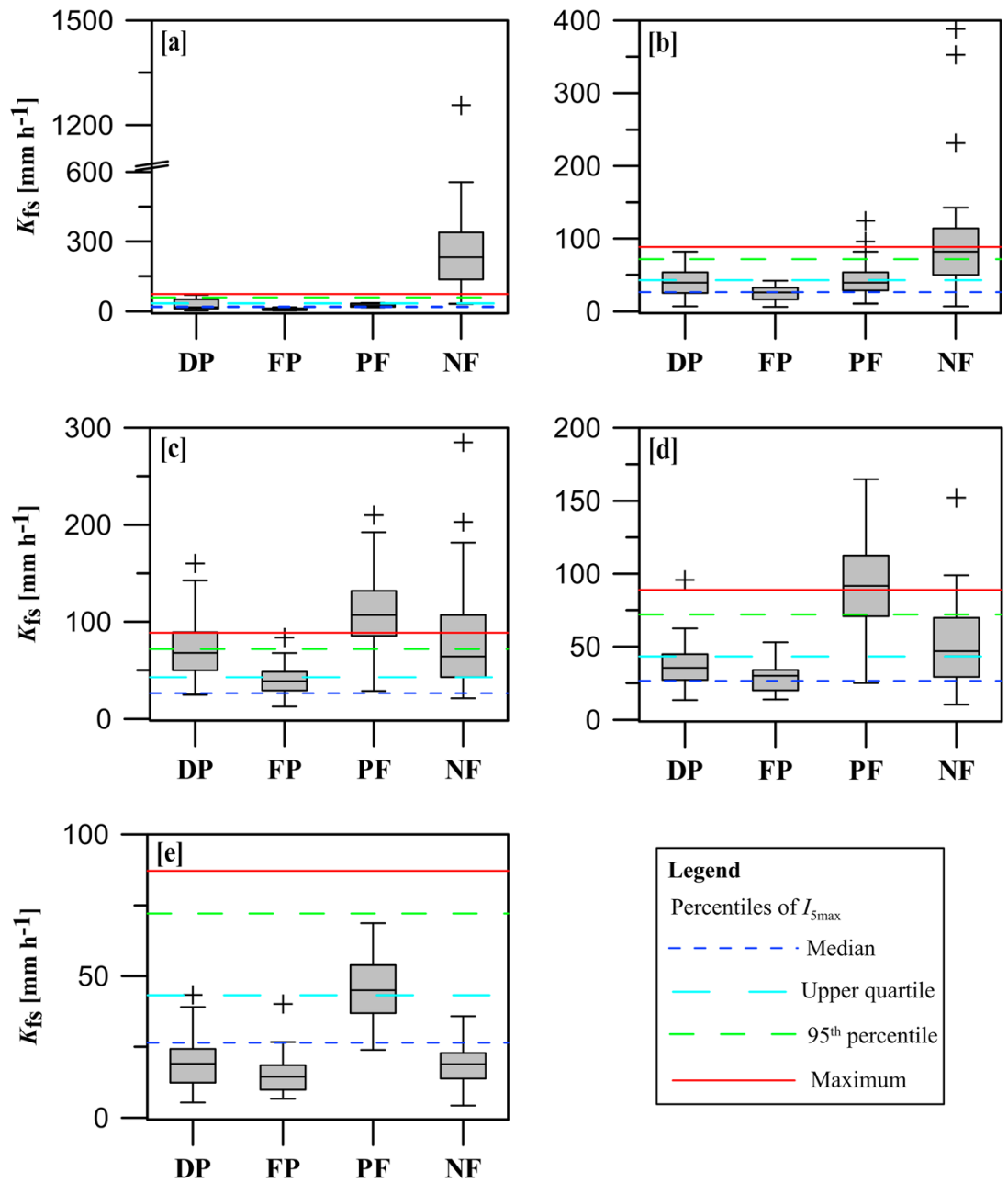

Figure 5. Field-saturated soil hydraulic conductivity $K_{\mathrm{fs}}$ as a function of land use and measurement depth in the headwaters of the Jikhu Khola catchment, Central Nepal: (a) surface, (b) 0.05-0.15 m, (c) 0.15$0.25 \mathrm{~m}$, (d) $0.25-0.50 \mathrm{~m}$, and (e) $0.50-1.0 \mathrm{~m}$. The solid horizontal line represents the maximum rainfall intensity over $5 \mathrm{~min}$ and the various dashed lines the median, $75 \%$ percentile, and 95\% percentile of $I_{5 \max }$ rainfall intensity. $\mathrm{DP}=$ degraded pasture, $\mathrm{FP}=$ footpath, $\mathrm{PF}=$ pine forest, and $\mathrm{NF}=$ natural forest.

were fitted using a number of standard semivariogram models: Gaussian, exponential and spherical, and the one with the smallest residual sum of squares was chosen as the best fit model [Webster and Oliver, 2007]. To compare the strength of the spatial correlation, the so-called nugget to sill ratio was used following the limits of Cambardella et al. [1994]. The nugget stands for the variance at zero separation distance whereas the sill represents the variance at the range [Webster and Oliver, 2007]. A variable is considered to be strongly spatially dependent if the nugget to sill ratio is $\leq 0.25$; a ratio of $0.25-0.75$ indicates a moderate dependence, and a ratio of 0.75 or more suggests a weak spatial autocorrelation [Cambardella et al., 1994].

\section{Results}

\subsection{Soil Physical and Chemical Properties}

[23] Table 1 summarizes the results of the soil textural and chemical analyses whereas the corresponding bulk densities are presented in Figure 4.
[24] As expected on the basis of the intensity of usage, topsoil bulk density values at the degraded pasture $\left(1.18 \pm 0.33 \mathrm{~g} \mathrm{~cm}^{-3}\right)$ and pine forest $\left(1.24 \pm 0.095 \mathrm{~g} \mathrm{~cm}^{-3}\right)$ sites were similar and significantly higher than those for the little disturbed natural forest $\left(0.93 \pm 0.082 \mathrm{~g} \mathrm{~cm}^{-3}\right)$ site (Figure 4$)$. The pine forest soil had the highest sand percentage at all investigated depths in comparison to the soils of the degraded pasture and natural forest (Table 1). Such differences in sand content are likely to contribute to the observed differences in field-saturated hydraulic conductivity $\left(K_{\mathrm{fs}}\right)$ (Table 2 below). Topsoil organic carbon content was highest in the natural forest $(4.10 \pm 0.25 \%)$ and differed significantly from values obtained for the other two sites (Table 1), indicating the greater activity of soil microflora and fauna feeding on the litter layer in the natural forest.

\subsection{Exploratory Analysis of Field-Saturated Hydraulic Conductivity}

[25] The descriptive statistics of $K_{\mathrm{fs}}$ for the various depth intervals at each site are presented in Table 2. As can be seen from the corresponding box plots (Figure 5), most of the $K_{\mathrm{fs}}$ data sets showed non-Gaussian behavior. Therefore, a global 
GHIMIRE ET AL.: REFORESTATION AND HILLSLOPE $K_{\mathrm{fs}}$

Table 3. Parameter Values for Those Semivariogram Model Models That Best Described the Observed Spatial Variability of FieldSaturated Hydraulic Conductivity $K_{\mathrm{fs}}$ With Depth as Associated With the Different Land-Cover Types in the Headwaters of the Jikhu Khola Catchment, Central Nepal ${ }^{\mathrm{a}}$

\begin{tabular}{|c|c|c|c|c|c|c|c|c|c|}
\hline & Soil Depth (m) & Model $^{\mathrm{b}}$ & Nugget & Partial Sill & Sill & Range (m) & Effective Range $(\mathrm{m})^{\mathrm{c}}$ & Nugget/Sill & Sserr $^{\mathrm{d}}$ \\
\hline Degraded pasture & $(0.05-0.15)$ & Exp & 0 & 2.37 & 2.37 & 1.8 & 5.4 & 0 & 0.76 \\
\hline Pine forest & & Sph & 0 & 2.3 & 2.3 & 4.4 & 4.4 & 0 & 5.66 \\
\hline Natural forest & & Sph & 0 & 0.5 & 0.5 & 4.4 & 4.4 & 0 & 0.35 \\
\hline Degraded pasture & $(0.15-0.25)$ & Sph & 1.5 & 1.68 & 3.19 & 9.2 & 9.2 & 0.47 & 0.65 \\
\hline Pine forest & & Sph & 0.81 & 2.66 & 3.5 & 6.5 & 6.5 & 0.23 & 0.65 \\
\hline Natural forest & & Exp & 0.27 & 0.038 & 0.308 & 6.5 & 19.5 & 0.9 & 0.01 \\
\hline Degraded pasture & $(0.25-0.50)$ & Sph & 0.8 & 0.9 & 1.7 & 10.5 & 10.5 & 0.47 & 0.18 \\
\hline Pine forest & & Sph & 0 & 2.67 & 2.67 & 4.8 & 4.8 & 0 & 2.87 \\
\hline Natural forest & & Sph & 0.11 & 0.38 & 0.49 & 15.0 & 15.0 & 0.22 & 0.22 \\
\hline Degraded pasture & $(0.50-1.0)$ & Exp & 0.55 & 0.41 & 0.96 & 4.5 & 13.5 & 0.57 & 0.028 \\
\hline Pine forest & & Sph & 0 & 0.88 & 0.88 & 4.1 & 4.1 & 0 & 1.17 \\
\hline Natural forest & & Sph & 0.13 & 0.18 & 0.31 & 14.8 & 14.8 & 0.42 & 0.023 \\
\hline
\end{tabular}

${ }^{a}$ See text for explanation.

${ }^{\mathrm{b}}$ Model type: Exp=Exponential; $\mathrm{Sph}=$ Spherical.

${ }^{c}$ For exponential model: Effective range $=$ range*3.

${ }^{\mathrm{d}}$ Sserr: Residual sum of squares.

comparison of the results obtained for different sites and depths was based on median values.

[26] As expected on the basis of the degree of anthropogenic pressure experienced by the respective sites, the median surface $K_{\mathrm{fs}}$ was lowest for the footpath $\left(12 \mathrm{~mm} \mathrm{~h}^{-1}\right)$ and highest for the natural forest $\left(232 \mathrm{~mm} \mathrm{~h}^{-1}\right)$, such that they differed by more than an order of magnitude (Table 2). Under the nearly undisturbed conditions prevailing in the natural forest, $K_{\mathrm{fs}}$ decreased with depth, particularly in the first $0.15 \mathrm{~m}$, although the difference between 0.15 and $1 \mathrm{~m}$ depth was still more than fourfold (Table 2 and Figure 5). The largest variance of $K_{\mathrm{fs}}$ at any depth within the natural forest was observed at 0.15 $0.25 \mathrm{~m}$ depth (Figure $5 \mathrm{c}$ ). A different pattern with depth was observed for the degraded pasture, footpath, and pine forest sites - which all had very low values of surface $K_{\mathrm{fs}}$ - in that here the near-surface $K_{\mathrm{fs}}$ first increased down to a depth of $0.25 \mathrm{~m}$ and then started to decrease (Table 2). Arguably, the most striking feature of the current data set is that the median $K_{\mathrm{fs}}$ at the surface and in the shallow soil layer in the 25 year old pine forest had remained at the same level as those for the heavily grazed degraded pasture, suggesting the virtual absence of nonstructural (i.e., biologically mediated) macropores within the pine forest's soil down to $0.15 \mathrm{~m}$ depth. This finding mirrors the pattern found earlier for topsoil $(0-10 \mathrm{~cm})$ bulk densities at the two sites (Figure 4).

[27] A statistical comparison of $K_{\mathrm{fs}}$ values measured at the surface and at a depth of $0.05-0.15 \mathrm{~m}$ between the pine forest, degraded pasture, and natural forest sites supported the preceding inferences in that there was no significant difference $(p>0.017)$ between the pine forest and degraded pasture, whereas both sites had significantly lower $(p<0.017)$ values compared to the natural forest, as also evidenced by the much lower topsoil bulk density of the natural forest (Figure 4). Below $0.15 \mathrm{~m}$ depth, however, the $K_{\mathrm{fs}}$ in the pine forest was consistently higher $(p<0.017)$ than values measured at any other site (Figures $5 \mathrm{c}-5 \mathrm{e}$ ), presumably because of a difference in soil texture (cf. Table 1). Moreover, the comparison between the footpath and degraded pasture showed no significant difference in surface $K_{\mathrm{fs}}$, indicating that surface conditions at the degraded pasture had already reached an extreme state of degradation. In contrast, $K_{\mathrm{fs}}$ values between 0.15 and $0.25 \mathrm{~m}$ depth differed significantly between the footpath and degraded pasture. At $1.0 \mathrm{~m}$ depth, however, differences in $K_{\mathrm{fs}}$ between the respective land-cover types were mostly nonexistent (except for the higher value beneath the pine forest already signaled), indicating the lack of influence exerted by cattle grazing and human trampling on the deeper soil layers.

\subsection{Spatial Structure}

[28] Experimental semivariograms (cf. equation (5)) were developed to describe the spatial structure of the subsurface $K_{\mathrm{fs}}$ data using the residuals of a square root transformation (degraded pasture and pine forest sites) or a $\log _{\mathrm{e}}$ transformation (natural forest) of the data. The results of the spatial analysis are summarized in Table 3.

[29] The spatial correlation length ("effective range") increased with depth throughout the profile underneath the degraded pasture but not in the pine forest or natural forest where the effective range first increased down to a depth

Table 4. Selected Statistical Parameters of Field-Saturated Hydraulic Conductivity $K_{\mathrm{fs}}\left(\mathrm{mm} \mathrm{h}^{-1}\right)$ for the $0.05-0.15 \mathrm{~m}$ Depth Interval After Including Only Every Alternate, Second, or Third $K_{\mathrm{fs}}$ Value From the Original Data Set to Remove the Effect of Spatial Correlation $^{\mathrm{a}}$

\begin{tabular}{lccc}
\hline & $@ 5 \mathrm{~m}$ & $@ 7.5 \mathrm{~m}$ & $@ 10 \mathrm{~m}$ \\
\hline \multirow{4}{c}{ Degraded Pasture } \\
Mean & $39(41)$ & $40(41)$ & $36(41)$ \\
Median & $39(39)$ & $39(39)$ & $39(39)$ \\
& \multicolumn{4}{c}{ Pine Forest } \\
Mean & $42(43)$ & $45(43)$ & $37(43)$ \\
Median & $36(39)$ & $43(39)$ & $32(39)$ \\
& \multicolumn{4}{c}{ Natural Forest } \\
Mean & $91(94)$ & $82(94)$ & $101(94)$ \\
Median & $73(82)$ & $93(82)$ & $78(82)$ \\
\hline
\end{tabular}

${ }^{\mathrm{a}}$ Values in parentheses correspond to the results obtained using the original measurement interval. 
GHIMIRE ET AL.: REFORESTATION AND HILLSLOPE $K_{\mathrm{fs}}$

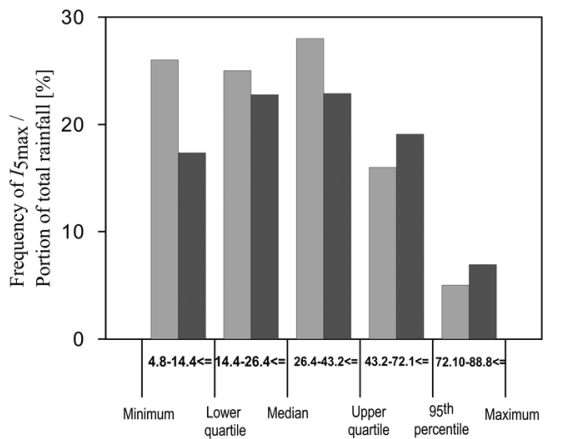

Percentiles of maximum 5-min rainfall intensity $\left[\mathrm{mm} \mathrm{h}^{-1}\right]$

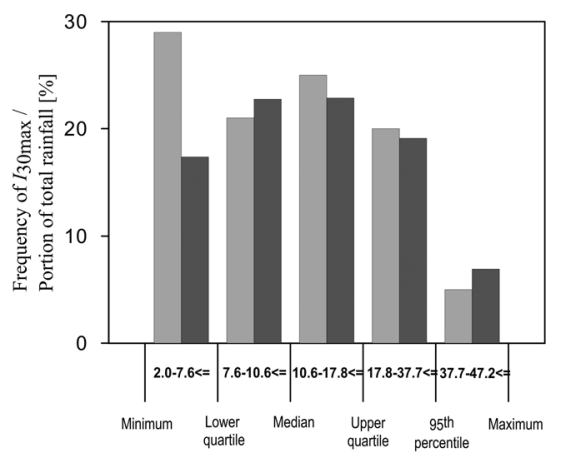

Percentiles of maximum 30-min rainfall intensity $\left[\mathrm{mm} \mathrm{h}^{-1}\right]$

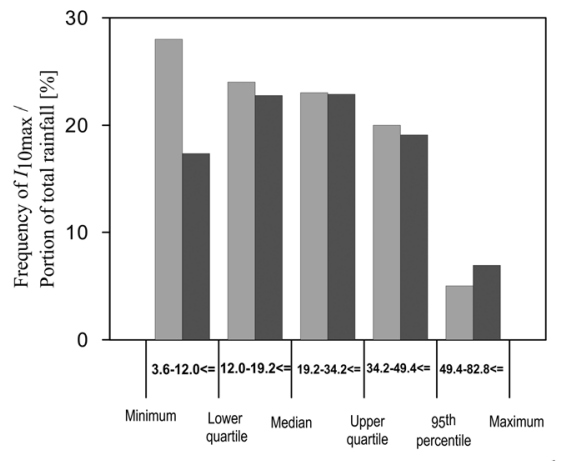

Percentiles of maximum 10-min rainfall intensity $\left[\mathrm{mm} \mathrm{h}^{-1}\right]$

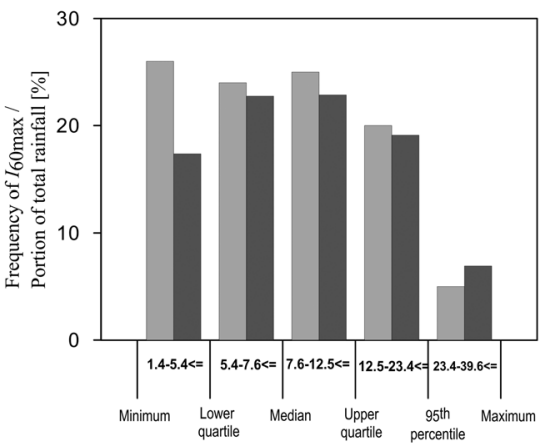

Percentiles of maximum 60-minute rainfall intensity $\left[\mathrm{mm} \mathrm{h}^{-1}\right]$

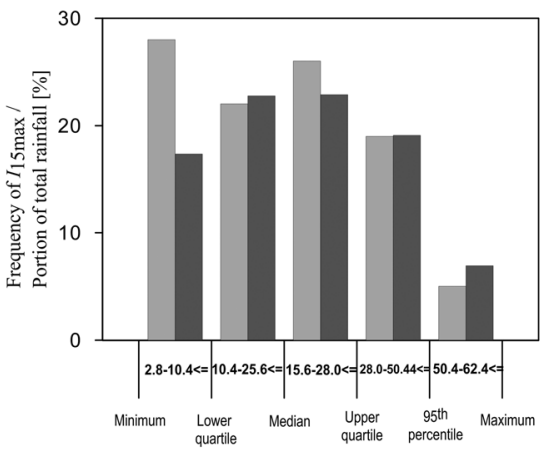

Percentiles of maximum 15-min rainfall intensity $\left[\mathrm{mm} \mathrm{h}^{-1}\right]$

Figure 6. Frequency and quantity of maximum 5, 10,30, and 60 min rainfall intensities as recorded at the Dhulikhel rainfall station, Central Nepal, during the 2010 and 2011 monsoon periods.

of $0.25 \mathrm{~m}$ and then started to decrease (Table 3 ). At a depth of $0.05-0.15 \mathrm{~m}$, all three land-cover types exhibited strong spatial dependence, with the correlation length ranging from $4.4 \mathrm{~m}$ (pine forest and natural forest) to $5.4 \mathrm{~m}$ (degraded pasture). For the $0.15-0.25 \mathrm{~m}$ depth interval, the most noticeable difference between sites was a much higher spatial correlation length under natural forest which, in addition, exhibited a weaker spatial dependence (as indicated by the higher nugget to sill ratio; Table 3). Spatial correlation lengths for the same depth interval in the degraded pasture and pine forest were similar and showed moderate (degraded pasture) to strong (pine forest) spatial dependence. At a depth of 0.25 $0.50 \mathrm{~m}$, both the pine forest and natural forest showed strong spatial dependence with correlation lengths ranging from 4.8 to $15.0 \mathrm{~m}$, respectively, whereas the degraded pasture indicated moderate spatial dependency with an effective range of $10.5 \mathrm{~m}$. Furthermore, between 0.50 and $1.0 \mathrm{~m}$ depth, the spatial correlation lengths in the degraded pasture and natural forest were similar and both showed moderate spatial dependence. As observed earlier for other depths, the spatial dependence in the deepest layer in the pine forest was very strong but had a low spatial correlation length $(4.1 \mathrm{~m}$; Table 3$)$. Overall, spatial correlations at or above the moderate category were detected at $0.05-015 \mathrm{~m}$ depth for all land covers and at greater depths for the degraded pasture and pine forest.

[30] To examine the effect of spatial correlation length for near-surface $(0.05-0.15 \mathrm{~m}) K_{\mathrm{fs}}$, new mean and median values for $K_{\mathrm{fs}}$ were calculated by including only every alternate, second, or third $K_{\mathrm{fs}}$ value from the original data set (Table 4). However, according to the Mann-Whitney $U$ test, the new median $K_{\mathrm{fs}}$ values did not differ significantly from the original ones.

\subsection{Rainfall Intensity, Overland Flow, and Hydrological Consequences of Anthropogenic Pressure}

[31] A total of 99 storm events were recorded during the summer monsoons of 2010 and 2011 at the Dhulikhel rainfall station. The maximum equivalent hourly intensities $\left(I_{5 \max }-I_{60 \max }\right)$ for the observed $5,10,15,30$, and $60 \mathrm{~min}$ rainfall classes for all storms over the two monsoon seasons were $88.8,82.8,62.4,47.2$, and $39.6 \mathrm{~mm} \mathrm{~h}^{-1}$, respectively.

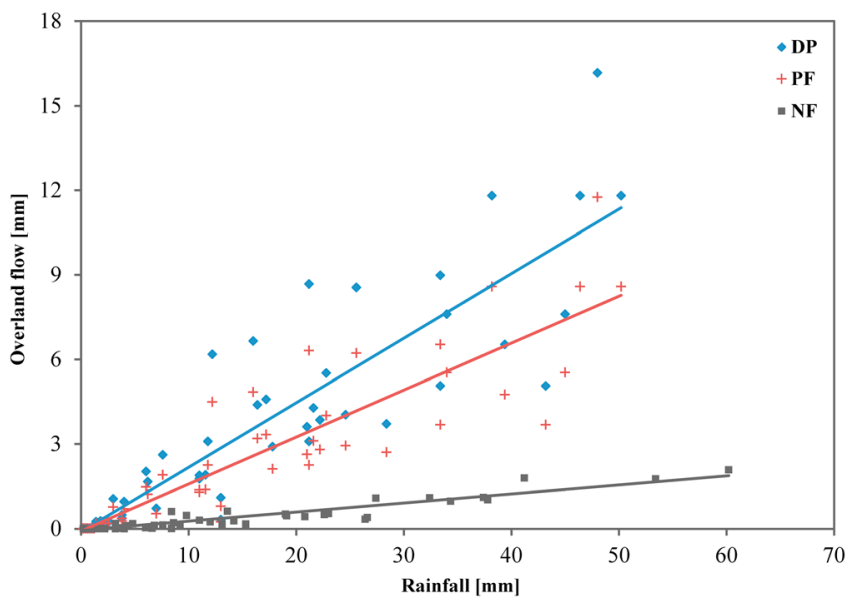

Figure 7. Relationships between daily rainfall $(\mathrm{mm})$ and overland flow (mm) during the 2011 monsoon measuring campaign for degraded pasture (DP), planted forest (PF), and natural forest (NF) in the headwaters of the Jikhu Khola catchment, Central Nepal. 
Table 5. Amounts of Rainfall, Throughfall, and Overland Flow During the 2011 Monsoon Measuring Campaign (20 June to 9 September) in Degraded Pasture (DP), Pine Forest (PF), and Natural Forest (NF) in the Headwaters of the Jikhu Khola Catchment, Central Nepal ${ }^{\mathrm{a}}$

\begin{tabular}{lccccc}
\hline & & & Overland & \multicolumn{2}{c}{ Overland Flow (\%) } \\
\cline { 5 - 6 } $\begin{array}{l}\text { Experimental } \\
\text { Plot }\end{array}$ & $\begin{array}{c}\text { Rainfall } \\
(\mathrm{mm})\end{array}$ & $\begin{array}{c}\text { Throughfall } \\
(\mathrm{mm})\end{array}$ & $\begin{array}{c}\text { Flow } \\
(\mathrm{mm})\end{array}$ & Rainfall & Throughfall \\
\hline $\mathrm{DP}$ & 878 & - & 187 & 21.3 & - \\
$\mathrm{PF}$ & 878 & 729 & 136 & 15.5 & 18.6 \\
NF & 709 & 540 & 17.7 & 2.5 & 3.3 \\
\hline
\end{tabular}

${ }^{a}$ Seasonal rainfall and throughfall totals taken from Ghimire et al. [2012].

The corresponding median values were $26.4,19.2,15.6,10.6$, and $7.6 \mathrm{~mm} \mathrm{~h}^{-1}$. For each rainfall intensity class, rainfall intensities were low for the majority of events. However, the higher-intensity storms contributed substantially to overall monsoon precipitation totals (Figure 6). The median, $75 \%$ percentile, $95 \%$ percentile, and absolute maximum values of $I_{5 \max }$ were selected as indices for inferring the dominant hillslope runoff pathways in combination with the results obtained for $K_{\mathrm{fs}}$ for the respective land covers (Figure 5).

[32] At only $12 \mathrm{~mm} \mathrm{~h}^{-1}$, the surface permeability of the heavily compacted footpath even remained below the median value of $I_{5 \max }$ (Figure 5a), suggesting the frequent occurrence of infiltration-excess overland flow (IOF). Although not measured on the footpath, IOF was indeed observed to occur more rapidly and in greater quantities during medium to high-intensity rainfall events than on the surrounding pasture (cf. Figure $2 \mathrm{~b}$ ). At the other extreme, the surface $K_{\mathrm{fs}}$ in the natural forest exceeded the maximum values of $I_{5 \max }$, suggesting IOF would never occur. Nevertheless, some overland flow was recorded at this site (Figure 7) with a

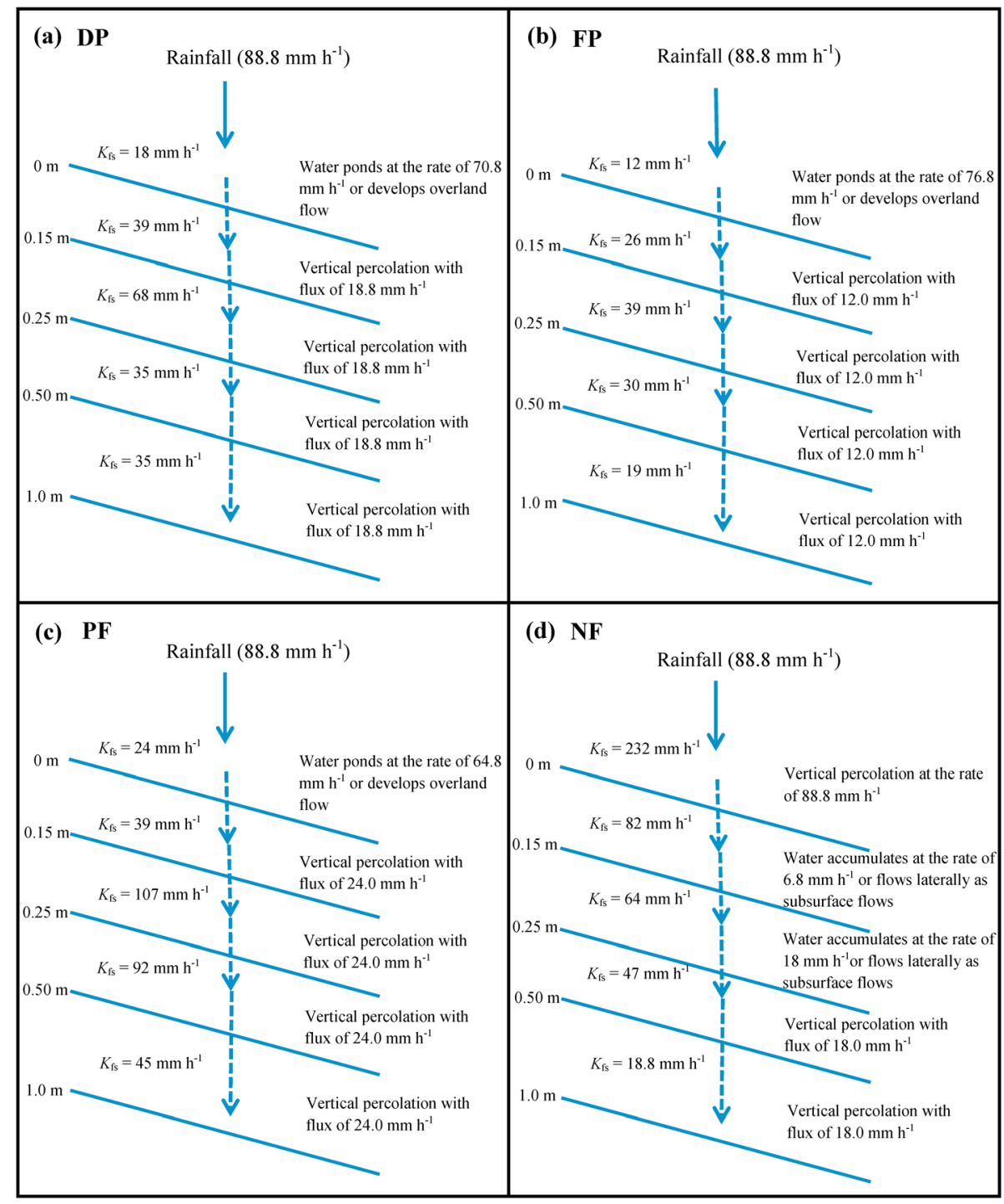

Figure 8. The percolation of rainfall delivered at the maximum $5 \mathrm{~min}$ intensity of $88.8 \mathrm{~mm} \mathrm{~h}^{-1}$ through various soil layers for contrasting land covers in the headwaters of the Jikhu Khola catchment, Central Nepal: (a) Degraded pasture (DP), (b) Footpath (FP), (c) Pine forest (PF), and (d) Natural forest (NF). $K_{\mathrm{fs}}$ is field-saturated hydraulic conductivity. 
monsoonal seasonal total of $17.7 \mathrm{~mm}$ or $2.5 \%$ of incident rainfall and $3.3 \%$ of the corresponding amount of throughfall (Table 5). Given the much lower median $K_{\mathrm{fs}}$ derived for the $0.05-0.15 \mathrm{~m}$ depth interval in the natural forest $\left(82 \mathrm{~mm} \mathrm{~h}^{-1}\right.$; Table 2), it cannot be excluded that at least some of the recorded overland flow was contributed by the saturationexcess type (SOF) [Bonell, 2005] (cf. Figure 8d). In spite of the slightly higher surface $K_{\mathrm{fs}}$ in the degraded pasture and pine forest compared to the footpath, the upper quartile of $I_{5 \max }$ still exceeded the median surface $K_{\mathrm{fs}}$ values for the grassland and pine reforestation (Figure $5 \mathrm{a}$ ), thereby indicating the occurrence of IOF during high-intensity rainfall (cf. Figures 7, 8a, and 8c). Indeed, overland flow at the degraded pasture site was typically generated after only 3$4 \mathrm{~mm}$ of rain (Figure 7) whereas the seasonal runoff total from the pasture amounted to $187 \mathrm{~mm}(21.3 \%$ of incident rainfall; Table 5). Corresponding values for the pine forest were comparable at $4.2 \mathrm{~mm}$ of rain before runoff would start (Figure 7) and a seasonal total of $136 \mathrm{~mm}$ (15.5\% of rainfall and $18.6 \%$ of throughfall; Table 5). However, a noticeable shift from IOF-dominated runoff to less impeded infiltration occurs when considering the maximum rainfall over $60 \mathrm{~min}$, i.e., moving from $I_{5 \max }$ to $I_{60 \max }$ (Figure 6).

[33] With regard to $K_{\mathrm{fs}}$ in the $0.05-0.15 \mathrm{~m}$ layer, the upper quartile of $I_{5 \max }$ exceeded the median $K_{\mathrm{fs}}$ values at the degraded pasture, footpath, and pine forest (Figure $5 \mathrm{~b}$ ). At such rates, the rainfall that percolates to this depth would be capable of developing a perched water table and with it generate lateral subsurface stormflow (SSF; Figures 8a-8c). This would be in addition to the concurrent occurrence of IOF at these sites. In contrast, the corresponding median $K_{\mathrm{fs}}$ at the natural forest is still above (or nearly equal to) most 5 min rainfall intensities (Figure 5b), thereby favoring mostly vertical percolation at this site (cf. Figure $8 \mathrm{~d}$ ).

[34] For the $0.15-0.25 \mathrm{~m}$ and $0.25-0.50 \mathrm{~m}$ depth intervals, the $K_{\mathrm{fs}}$ values in the degraded pasture, footpath, and natural forest all indicate a similar hydrological response to rainfall, namely mostly lateral SSF and thus limited vertical percolation during high-intensity rainfall (Figures $8 \mathrm{a}, 8 \mathrm{~b}$, and 8d). However, the much higher median values of $K_{\mathrm{fs}}$ between $0.15 \mathrm{~m}$ and $0.50 \mathrm{~m}$ depth at the pine forest site exceeded the maximum values of $I_{5 \max }$ (Figures $5 \mathrm{c}, 5 \mathrm{~d}$, and $8 \mathrm{c}$ ) and thus rather favor vertical percolation. These high conductivities are likely to reflect the higher sand content of the soil beneath the pine forest (Table 1) and effectively rule out the frequent occurrence of a perched water table and SSF in this layer, in contrast to what was inferred for the other sites. The effect, however, must be counteracted to some extent by the lowmedian surface $K_{\mathrm{fs}}$ in the pine forest which encourages IOF (Figures 5a, 7, and 8c) and restricts the amounts of water percolating to deeper layers. Finally, at $1.0 \mathrm{~m}$ depth, the differences in $K_{\mathrm{fs}}$ and inferred hydrological response to rainfall became insignificant between sites (Figure 5e).

\section{Discussion}

\subsection{The Impacts of Land Use/Land Cover on Spatial Correlation Length and Field-Saturated Soil Hydraulic Conductivity $\boldsymbol{K}_{\mathrm{fs}}$}

[35] The spatial analysis has highlighted some important issues. The fact that the new median $K_{\mathrm{fs}}$ values calculated by including only every alternate, second, or third $K_{\mathrm{fs}}$ indicates that the spatial correlation length had little or no effect on the conclusions derived from the entire data set or from the subsequently reduced sample populations. This suggests that the near-surface $K_{\mathrm{fs}}$ values for the degraded pasture, pine forest, and natural forest sites are more strongly associated with spatially independent random variation. On the other hand, the increase in spatial correlation length with depth throughout the profile beneath the degraded pasture is comparable to that reported for degraded pasture land in the mountains of south Ecuador [Zimmermann and Elsenbeer, 2008]. Similarly, the currently found increase in spatial correlation length down to a depth of $0.25 \mathrm{~m}$ and the subsequent decrease with depth is also a known characteristic of little disturbed natural forest soils elsewhere [Zimmermann and Elsenbeer, 2008]. Although the spatial correlation length in the pine forest first increased and then started to decrease, as was also observed in the natural forest, the pine forest is exceptional in that there was little variation in spatial correlation length with depth. In summary, no general depth-related spatial pattern was observed across all three study sites.

[36] The present work has further highlighted a marked contrast in the changes in $K_{\mathrm{fs}}$ with depth between the natural forest and the other two land covers studied (pine forest and degraded pasture). The reported high $K_{\mathrm{fs}}$ in the surficial soil horizons $(<0.25 \mathrm{~m})$ of the natural forest and the subsequent decrease in $K_{\mathrm{fs}}$ with depth away from direct soil biological influences (cf. the diminishing SOC values with depth listed in Table 1) is a well-known characteristic of soils beneath little disturbed tropical forests [Elsenbeer, 2001; Bonell, 2005; Chappell et al., 2007]. The data from the natural forest provide a "baseline" for appreciating the marked reductions in $K_{\mathrm{fs}}$, especially at depths less than $0.25 \mathrm{~m}$, within the soils of the intensely disturbed degraded pasture, and pine forest due to multidecadal human-induced pressures as also reported for a similar situation elsewhere in the Middle Mountains of Nepal by Ghimire et al. [2013].

[37] Major decreases in surface- and near-surface $K_{\mathrm{fs}}$ following the conversion of forest to grazed pasture have been reported for a variety of tropical and subtropical settings [Alegre and Cassel, 1996; Tomasella and Hodnett, 1996; Deuchars et al., 1999; Zimmermann et al., 2006; Molina et al., 2007; Tobón et al., 2010] including the Himalaya [Patnaik and Virdi, 1962; Gardner and Gerrard, 2002; Ghimire et al., 2013]. Moreover, the noted reversal in the trend of $K_{\mathrm{fs}}$ with depth (i.e., an initial increase in $K_{\mathrm{fs}}$ followed by a decrease) beneath the degraded pasture and pine forest is a characteristic in common with other reports where grazing and other soil compacting pressures have been sustained over decades [e.g., Tomasella and Hodnett, 1996; Godsey and Elsenbeer, 2002; Hamza and Anderson, 2005; Zimmermann et al., 2006]. Furthermore, it is clear that the hydraulic conductivity of the pine forest soil 25 years after the trees were planted still reflects the influence of the previous degraded grassland that is further sustained by the continued human access and collection of forest products [cf. Singh and Sundriyal, 2009; Joshi and Negi, 2011; Ghimire et al., 2013]. As most of the reduction in $K_{\mathrm{fs}}$ appears to be effected during the first few years of grazing (particularly in the case of mechanized forest conversion followed by intensive grazing) [cf. Alegre and Cassel, 1996; Martinez and Zinck, 2004; Zimmermann et al., 2010], one would expect comparatively little additional effect of multidecadal grazing on infiltrability. Indeed, at $23-29 \mathrm{~mm}$ 
$\mathrm{h}^{-1}$, the reported rates of surface $K_{\mathrm{fs}}$ after 20-30 years of grazing [Deuchars et al., 1999; Colloff et al., 2010; Hassler et al., 2011] are very similar to the values obtained for the very degraded Himalayan pastures of the current study (median $18 \mathrm{~mm} \mathrm{~h}^{-1}$, mean $K_{\mathrm{fs}} 25 \mathrm{~mm} \mathrm{~h}^{-1}$; Table 2) and at Chautara (log-mean values of 33-39 $\mathrm{mm} \mathrm{h}^{-1}$ ) [Gilmour et al., 1987; Ghimire et al., 2013]. The radical reduction in surfaceand near-surface $K_{\mathrm{fs}}$ under grazing conditions is primarily related to the destruction of macroporosity by trampling and by the strongly diminished soil biological activity after forest clearing and prolonged exposure of topsoil to the elements [cf. McIntyre, 1958a, 1958b; Lal, 1988; Deuchars et al., 1999; Colloff et al., 2010; Bonell et al., 2010]. Therefore, natural forest regrowth or reforestation on former degraded pasture land is considered by many to be an effective way of restoring diminished $K_{\mathrm{fs}}$, although it may well take several decades of uninterrupted forest development before the infiltrability of highly degraded pasture reaches that associated with near-natural conditions [Gilmour et al., 1987; Godsey and Elsenbeer, 2002; Ziegler et al., 2004a, 2004b; Zimmermann et al., 2010; Hassler et al., 2011]. However, the current results, and to a lesser extent the related work by Ghimire et al. [2013] in the Chautara area, suggest that this one-dimensional view of restoring diminished surface- and near-surface $K_{\mathrm{fs}}$ requires some modification. This is particularly true in cases where anthropogenic pressures on both natural forests and tree plantations are as high as in the Middle Mountain Zone of the Himalaya [cf. Singh and Singh, 1992; Mahat et al., 1987; Singh and Sundriyal, 2009; Joshi and Negi, 2011; Gilmour and Shah, 2012]. Indeed, one of the most striking findings of the present study is that the soil hydraulic conductivities at the surface and at a depth of $0.05-0.15 \mathrm{~m}$ in the 25 year old pine reforestation did not differ significantly from those of the 150 year old heavily degraded pasture, implying very similar hydrological response to rainfall (i.e., enhanced occurrence of IOF; cf. Figures 5a, 5b, 7, and 8c).

\section{2. $K_{\mathrm{fs}}$, Overland Flow Generation, and Forest Management}

[38] It was previously acknowledged that the presently collected $K_{\mathrm{fs}}$ data are more likely to be representative of the higher end of the seasonal spectrum of this variable due to the fact that the measurements were undertaken during the latter part of a long dry season. Nonetheless, the rank order of measured seasonal overland flow totals (cf. Table 5; Figure 7) essentially reflects the a priori inferred stormflow pathways when comparing rainfall intensity with $K_{\mathrm{fs}}$ (Figures 5 and 8). For example, monsoonal totals of overland flow generated at the pine forest $(15.5 \%$ of rainfall but $18.6 \%$ of throughfall) and the degraded pasture (21.3\% of rainfall) were comparable (Table 5), as were their surface $K_{\mathrm{fs}}$ values (Table 2). Likewise, the very low overland flow occurrence measured in the natural forest (Table 5 and Figure 7) is also supported by the results of the $K_{\mathrm{fs}}$ survey, especially when it is taken into account that $K_{\mathrm{fs}}$ values during the main monsoon are likely to be lower than the ones determined during the dry season [Bonell et al., 2010]; see also Vigiak et al. [2006] for a discussion of the representativity of different techniques to measure surface $K_{\mathrm{fs}}$.

[39] High to very high incidence of overland flow on degraded pastures elsewhere in the Himalayas and Southeast
Asia has been reported previously [Impat, 1981; Chandler and Walter, 1998; Gerrard and Gardner, 2002; cf. Bruijnzeel and Bremmer, 1989] but not for mature ( $>20$ years old) pine plantations whose $K_{\mathrm{fs}}$ values are usually sufficient to accommodate high rainfall intensities [Waterloo, 1994; cf. Ilstedt et al., 2007]. It has been suggested that pine litter enhances surface soil water repellency and thus IOF generation relative to conditions encountered in broad-leaved forests, particularly for volumetric topsoil moisture levels $(\theta)$ below $0.2 \mathrm{~m}^{3} \mathrm{~m}^{-3}$ and $\mathrm{pH}$ values between 4 and 4.5 [Lebron et al., 2012]. However, neither $\theta$ during monsoon conditions nor topsoil $\mathrm{pH}$ in the pine forest $(5.42 \pm 0.28, n=9)$ could be considered conducive to soil water repellency in the presently studied pine forest. In addition, overland flow in undisturbed pine forest in the more seasonal (and thus likely to experience drier conditions) Kumaon Himalaya (Northwest India) proved negligible [Pathak et al., 1984]. Only where the trees are planted on heavy clay soils (as is often the case for teak) do $K_{\mathrm{fs}}$ values not show any improvement during plantation maturation [Mapa, 1995; Bonell et al., 2010] and can overland flow be rampant [Coster, 1938; Bell, 1973; Wiersum, 1984]. Likewise, where the development of a protective forest floor (litter layer, herb layer, and understory) is interrupted repeatedly by fire, grazing, or litter harvesting, the improvement of surface $K_{\mathrm{fs}}$ may be arrested (as observed in the pine forest, Table 2) or even be reversed as the plantation matures [Ghimire et al., 2013]. However, even in the absence of trampling pressure, the combination of repeated litter removal, enhanced erosive power of crown drip [Wiersum, 1985; Hall and Calder, 1993], and reduced soil biotic activity [Ding et al., 1992; Hairiah et al., 2006] sets in motion a downward spiral toward a gradually diminishing infiltration capacity and a corresponding increase in overland flow production [Coster, 1938; Tsukamoto, 1975; Wiersum, 1984, 1985; Tiwari et al., 2009].

\subsection{Implications for Dry Season Streamflow}

[40] The present finding of diminished infiltration opportunities in the pine forest and other similarly heavily used forests [Gardner and Gerrard, 2002; Zhou et al., 2002; Tiwari et al., 2009; Ghimire et al., 2013] may prove critical when interpreting reports of declining stream base flows following large-scale reforestation in the Middle Mountains of Central Nepal [República, 2012]. Although reduced annual streamflow totals (and presumably base flows as well) after afforesting nondegraded grasslands with fast-growing pines have been documented for many places (summarized by Jackson et al. [2005] and Scott et al. [2005]), dry season flows may be expected to increase following reforestation of (heavily) degraded pasture land if the associated gains through improved rainfall infiltration override the extra evapotranspiration of the planted trees (the so-called "infiltration tradeoff" hypothesis) [Bruijnzeel, 1989; Bruijnzeel 2004; cf. Wilcox and Huang, 2010; Zhou et al., 2010; Krishnaswamy et al., 2013].

[41] As such, it is of interest to explore the possible consequences of the presently observed high overland flow volumes in the pine forest in the context of the infiltration trade-off hypothesis more closely. Combining the above mentioned overland flow percentages for the pine forest and degraded pasture with the mean annual site rainfall of $1500 \mathrm{~mm}[\mathrm{Merz}$, 2004], the difference in approximate annual overland flow production between the two land covers represents a gain in 
GHIMIRE ET AL.: REFORESTATION AND HILLSLOPE $K_{\mathrm{fs}}$

infiltration of approximately $90 \mathrm{~mm} \mathrm{yr}^{-1}$ under the pines relative to the grassland. Preliminary work on soil water uptake (transpiration) in the degraded pasture and pine forest [Baral, 2012], plus the rainfall interception losses from the pine forest and natural forest established by Ghimire et al. [2012] suggest a difference in annual evapotranspiration (ET) between the degraded pasture and pine forest of 360 $400 \mathrm{~mm}$, i.e., greatly in excess of the estimated gain in infiltration of $90 \mathrm{~mm}$ and in line with locally perceived declines in streamflow. Pertinently, even if the pine forest would have been well-managed and capable of absorbing even the highest rainfall intensities (i.e., no IOF occurrence and thus implying a maximum gain in infiltration equal to the observed overland flow total at the degraded pasture site of $\sim 320 \mathrm{~mm} \mathrm{yr}^{-1}$ ), this would still not have been sufficient to compensate the higher water use of the pines and thus prevent a decline in streamflow. Repeating the exercise for the natural forest (with an estimated annual ET close to $500 \mathrm{~mm}$ [Baral, 2012; Ghimire et al., 2012] and very low overland flow production) would suggest the ultimate effect on dry season flows to be near-neutral as the approximate gain in infiltration and the extra evaporative loss are very similar (ca. $300 \mathrm{~mm} \mathrm{yr}^{-1}$ each). However, in view of the widespread regeneration of vegetation on abandoned agricultural fields in the Middle Mountain Zone [Paudel et al., 2012] and because water use by vigorously regenerating forest tends to exceed that of old-growth forest like that of the natural forest site [cf. Giambelluca, 2002; Hölscher et al., 2005; Muñoz-Villers et al., 2012], it may be several decades before regional streamflows can be expected to stabilize or even rebound [cf. Wilcox and Huang, 2010; Zhou et al., 2010; Beck et al., 2013]. Moreover, recent studies have reported an increasing trend in total monsoonal precipitation and extreme events in recent years for the Middle Mountain Zone and other parts of Nepal [Baidya et al., 2008; Lamichhane and Awasthi, 2009]. Furthermore, application of a high-resolution climate model elsewhere in the Middle Mountain Zone by Mishra and Herath [2011] indicated a significant increase in rainfall and rainfall intensity during the monsoon season and a decrease in dry season rainfall. These scenarios suggest that there may be (much) more overland flow from planted forest sites in the future if the presently observed anthropogenic pressures on the forest do not decrease. Such circumstances will further hamper the replenishment of soil water and groundwater reserves, thereby reducing dry season flows even further. On the other hand, the high-surface and near-surface $K_{\mathrm{fs}}$ observed in the little disturbed natural forest suggests that this type of forest may be able to cope with increased rainfall intensities in the future provided it does not become disturbed too much.

[42] Overall, the present work has highlighted a "degradation" in $K_{\mathrm{fs}}$ at the surface and near surface in the planted forest site. The potential benefits of reforestation in enhancing infiltration, and therefore the replenishment of soil water and groundwater reserves, are currently not realized by the continued need for access to the forest by the local population to obtain forest products (notably litter for animal bedding and subsequent composting), with sustained degradation of the forest floor as a result. The notion of forests established primarily for community needs vis á vis broader drainage basin functions is a point commonly ignored in forest hydrology where the focus tends to be placed more on the hydrological benefits of forests per se (i.e., without people) [e.g.,
Webb et al., 2012; Krishnaswamy et al., 2013]. Such circumstances are common in the South Asian region

\subsection{Footpaths as Source Areas of Storm Runoff}

[43] Evidence is accumulating for various tropical and subtropical uplands-including the present study area-that rural footpaths, cattle trails within pastures, and rural yards can play a significant role in the generation of overall hillslope-scale IOF and accelerated erosion [Rijsdijk and Bruijnzeel, 1991; Giambelluca, 1996; Purwanto, 1999; Van Dijk, 2002; Ziegler et al., 2004a, 2004b; Rijsdijk et al., 2007; Turkelboom et al., 2008; Tobón et al., 2010]. These highly compacted surfaces can have extremely low surface infiltrabilities $\left(<10 \mathrm{~mm} \mathrm{~h}^{-1}\right.$ in many of the examples cited above) and therefore they can be expected to exhibit a strong propensity toward producing IOF even during comparatively low-rainfall intensities (cf. Figures $2 \mathrm{~b}$ and 5a). For example, Rijsdijk et al. [2007] reported runoff coefficients of up to $70 \%$ for rural footpaths in the mountains of East Java, Indonesia. Indeed, in addition to the very low surface infiltrability of the presently studied footpath (Table 2), median $K_{\mathrm{fs}}$ values at $0.05-0.15 \mathrm{~m}$ and $0.15-25 \mathrm{~m}$ depths beneath the footpath were close to the median value of $I_{5 \max }$ and well below the $75 \%$ and $95 \%$ percentiles of $I_{5 \max }$ (Figures $5 \mathrm{~b}$ and $5 \mathrm{c}$ ), suggesting frequent occurrence of IOF. Footpath-related IOF can be particularly harmful in that footpaths, despite their relatively small areal extent, can contribute disproportionally to catchment-scale storm runoff and sediment yield [Dunne and Dietrich, 1982; Ziegler and Giambelluca, 1997; Ziegler et al., 2004b; Cuo et al., 2006; Turkelboom et al., 2008]. Moreover, the transmission rate of IOF from footpaths to streams can be (very) fast, owing to their connectivity with and proximity to the streams. This is particularly true in the densely populated Middle Mountain Zone within the Himalaya where numerous footpaths typically run steeply uphill from the riparian zone. Footpath-related IOF is even more critical in the absence of downslope buffering zones with higher $K_{\mathrm{fs}}$ to dampen the flow [cf. Ziegler et al., 2004a, 2004b; Turkelboom et al., 2008]. This was also the case in the present study area where the footpath was surrounded by degraded pasture and poorly managed pine forest, both having low surface and near-surface $K_{\mathrm{fs}}$ (Table 2). Collectively, such footpath-related IOF in combination with buffering zones of low-infiltration capacity can be expected to elevate local-scale flash floods [see examples discussed by Bruijnzeel and Bremmer, 1989].

\subsection{On the Need to Protect the Remaining Natural Forests of the Middle Mountains}

[44] At the other end of the runoff-generation spectrum, the median surface and near-surface $K_{\mathrm{fs}}$ values in the little disturbed natural forest (Table 2) were such that even under conditions of intense rainfall, vertical percolation was indicated as the dominant initial hydrological pathway, only subsequently to become diverted laterally as SSF below $0.15 \mathrm{~m}$ depth during the most intense rainfalls (Figures $5 \mathrm{c}, 5 \mathrm{~d}$, and 8d). Therefore, conditions in the natural forest and similarly well-maintained forests elsewhere in the Himalaya [Pathak et al., 1984; Gardner and Gerrard, 2003] will encourage the replenishment of soil water and groundwater reserves through vertical percolation more than in any of the other land-cover types studied (Figures 5 and 8d) and thus better 
sustain base flows during the long dry season for community water supply. The importance of the latter can hardly be overstated [cf. Merz et al., 2003; Schreier et al., 2006; Bandhyopadhyay, 2013].

[45] The abundance of macropores arising from the decomposing activity of soil microflora and fauna associated with the higher organic matter inputs to the forest floor in undisturbed forests (cf. Table 1) is considered a prime reason for the commonly observed high-infiltration capacity and near-surface $K_{\mathrm{fs}}$ of such forest soils, together with a well-developed root system [Lal, 1988; Deuchars et al., 1999; Bonell, 2005; Zimmermann and Elsenbeer, 2008; Bonell et al., 2010]. The results presently obtained for the natural forest and pine forest once more illustrate the importance of a well-developed litter layer and understory vegetation to hillslope hydrological functioning [cf. Pathak et al., 1984]. Indeed, the presence of a dense shrub layer and a thick litter layer were considered to be the chief causal factors of the observed soil-protective and rainfall-absorbing role of degraded natural forest studied by Ghimire et al. [2013] in the Chautara area. Elsewhere in the Middle Mountain Zone, Tiwari et al. [2009] describe a case where overland flow and sediment production in a community-managed broad-leaved forest under a restricted tree pruning and grazing regime greatly exceeded that in nearby unmanaged forest. Although pruning and grazing were restricted in the latter forest, ground cover by undergrowth and litter was much better compared to the community-managed forest where litter and understory vegetation were regularly harvested and left the forest floor unprotected [cf. Coster, 1938; Wiersum, 1985; Tiwari et al., 2009]. The present results also underscore the hydrological importance of preserving the remaining natural forests of the Middle Mountain Zone [cf. Pathak et al., 1984; Negi et al., 1998; Singh, 2007; Ghimire et al., 2013].

\section{Conclusions}

[46] To shed more light on the impact of reforesting degraded hillsides on surface and subsurface hydrological functioning, field-saturated hydraulic conductivities $\left(K_{\mathrm{fs}}\right)$ were measured in a little disturbed natural forest, a heavily degraded pasture, an intensively used footpath, and a mature planted pine forest subject to considerable anthropogenic pressure in complex and rugged terrain near Dhulikhel, Central Nepal.

[47] The high surface and near-surface $K_{\mathrm{fs}}$ observed in the natural forest effectively prevented the occurrence of largescale infiltration-excess overland flow (IOF) even for the most extreme rainfall events. Thus, natural forest favors largely the vertical percolation and the replenishment of soil water and groundwater reserves. Conversely, very low surface and near-surface $K_{\mathrm{fs}}$ were found in the degraded pasture (18$\left.39 \mathrm{~mm} \mathrm{~h}^{-1}\right)$ and particularly for the footpath $\left(12-26 \mathrm{~mm} \mathrm{~h}^{-1}\right)$ which encouraged the generation of IOF even during events with moderate rainfall intensities. The large volumes of overland flow generated on footpaths and degraded pastures in the study area can be expected to contribute disproportionally to local-scale stormflows due to the absence of well-developed footslope buffer zones of sufficiently high $K_{\mathrm{fs}}$ and the fact that many footpaths cross steep hillsides, thereby providing rapid transfer of IOF to the nearest stream.
[48] Various human interventions (notably the regular collection of litter from the forest floor for animal bedding, plus understory removal by cattle grazing and fuelwood harvesting) in the planted pine forest had not allowed any improvement in $K_{\mathrm{fs}}$ over 25 years. In fact, surface and nearsurface $K_{\mathrm{fs}}$ and IOF volumes in the pine forest had remained similar to those observed at the nearby degraded pasture site (i.e., the situation prior to reforestation). Reforestation of degraded hillslopes per se, therefore, does not guarantee the improvement of soil infiltration capacity and the restoration of hillslope hydrological functioning. The corresponding reduced infiltration must be considered a critical factortogether with the higher water use of the pine trees compared to old-growth broad-leaved forest-when interpreting the presently perceived decline in dry season flows in the Middle Mountains of Central Nepal.

[49] The present results further illustrate the positive influence of a well-developed litter layer and understory vegetation on surface and subsurface hydrological functioning. They also bring out the hydrological importance of preserving the remaining old-growth forests of the Middle Mountain Zone of the Nepalese and Indian Himalaya. Continued degradation of the remaining old-growth vegetation and planted forests can be expected to lead to further increased storm runoff across the zone's river network during the main monsoon season due to the corresponding reduction of surface and shallow subsurface $K_{\mathrm{fs}}$, which may, in turn, have a further detrimental effect on already declining dry season flows because of further impaired replenishment of soil water and groundwater reserves.

[50] Acknowledgments. This study was supported financially by the Faculty of Earth and Life Sciences of the VU University Amsterdam (FALW-VUA) and by the Faculty of Geo-information Science and Earth Observation (ITC-UT) of the University of Twente, Enschede, The Netherlands. The Royal Society of the UK is acknowledged for providing travel support to the second author. We acknowledge the indispensable help of Sudish Lal Maskey, Kapil Gyawali, Dawa Lama, Gopal Nakarmi, Umesh Karki, and Laxman Baniya during the fieldwork. We especially would like to thank Pruna Bahadur Magar and his family for their hospitality and support during the field campaign. We are indebted to Hans Bakker (FALW-VUA) for the construction of the Talsma permeameter and the Centre for Ecohydrology (University of Western Australia) for providing the disc permeameter. Martina Hagen and W.K. Wentink (FALW-VUA) are thanked for conducting the soil textural analyses whereas Boudewijn de Smeth (ITC - UT) provided further support. The manuscript benefitted from the constructive comments received from the associate editor, Nick Chappell, Jagdish Krishnaswamy, and Conrado Tobón which are all gratefully acknowledged.

\section{References}

Alegre, J. C., and D. K. Cassel (1996), Dynamics of soil physical properties under alternate systems to slash-and-burn, Agric. Ecosyst. Environ., 58(1), 39-48, doi:10.1016/0167-8809(95)00654-0.

Allen, R. G., L. S. Pereira, D. Raes, and M. Smith (1998), Crop Evapotranspiration - Guidelines for Computing Crop Water Requirements, FAO, Rome.

Baidya, S. K., M. L. Shrestha, and M. M. Sheikh (2008), Trends in daily climatic extremes of temperature and precipitation in Nepal, J. Hydrol. Meteorol., 5(1), 38-51.

Bandhyopadhyay, J. (2013), Sustaining the Himalaya as the water tower of Asia: On the need for innovative policy making from India and China, 19th Pundit Govind Ballabh Pant memorial lecture, 10 September 2013, G.B. Pant Institute of Himalayan Environment and Development, Almora, India, 19 pp.

Baral, T. (2012), Evapotranspiration from natural and pine forest in the Middle Mountains of Nepal, MSc Thesis, 54 pp., Faculty of GeoInformation Science and Earth Observation of the University of Twente, Enschede, The Netherlands. 
Bartarya, S. K. (1989), Hydrogeology, geo-environmental problems and watershed management strategies in a central Himalayan river basin, Kumaun, India, in Headwater Control, edited by J. Kreek and M. J. Haigh, pp. 308-318, IUFRO/WASWC/CSVIS, Plzen, Czechoslovakia.

Beck, H. E., L. A. Bruijnzeel, A. I. J. M. Van Dijk, T. R. McVicar, F. N. Scatena, and J. Schellekens (2013), The impact of forest regeneration on streamflow in 12 meso-scale humid tropical catchments, HESS, 17, 2613-2635, doi:10.5194/hess-17-2613-2013.

Bell, T. I. W. (1973), Erosion in the Trinidad teak plantations, Commonw. For. Rev., 52, 223-233.

Blake, G. R., and K. H. Hartge (1986), Bulk density, in Methods of Soil Analysis. Part 1. Physical and Mineralogical Methods, edited by A Klute, pp. 363-376, American Society of Agronomy, Soil Science Society of America, Madison, Wisconsin, USA.

Bodhinayake, W., B. C. Si, and K. Noborio (2004), Determination of hydraulic properties in sloping landscapes from tension and double-ring infiltrometers, Vadose Zone J., 3, 964-970, doi:10.2136/vzj2004.0964.

Bonell, M. (2005), Runoff generation in tropical forests, in Forests, Water and People in the Humid Tropics, edited by M. Bonell and L. A. Bruijnzeel, pp. 314-406, Cambridge Univ. Press, Cambridge, U. K.

Bonell, M., D. A. Gilmour, and D. S. Cassells (1983), Runoff generation in tropical rainforests of northeast Queensland, Australia, and the implications for land use management, 140, 287-298, IAHS Publ.

Bonell, M., B. K. Purandara, B. Venkatesh, J. Krishnaswamy, H. A. K. Acharya, U. V. Singh, R. Jayakumar, and N. Chappell (2010), The impact of forest use and reforestation on soil hydraulic conductivity in the Western Ghats of India: Implications for surface and sub-surface hydrology, J. Hydrol., 391(1-2), 47-62, doi:10.1016/j. jhydrol.2010.07.004.

Bruijnzeel, L. A. (1989), (De)forestation and dry season flows in the tropics: A closer look, J. Trop. For. Sci., 1, 229-243.

Bruijnzeel, L. A. (2004), Hydrological functions of tropical forests: Not seeing the soil for the trees?, Agric. Ecosyst. Environ., 104(1), 185-228, doi:10.1016/j.agee.2004.01.015

Bruijnzeel, L. A., and C. N. Bremmer (1989), Highland-Lowland Interactions in the Ganges-Brahmaputra River Basin: A Review of Published Literature, ICIMOD Occasional Paper no. 11, 136 pp., ICIMOD, Kathmandu.

Cambardella, C. A., T. B. Moorman, T. B. Parkin, D. L. Karlen, J. M. Novak, R. F. Turco, and A. E. Konopka (1994), Field-scale variability of soil properties in central Iowa soils, Soil Sci. Soc. Am. J., 58(5), 1501-1511, doi:10.2136/sssaj1994.03615995005800050033x.

Campbell, R. J., and T. B. S. Mahat (1975), A practical approach to the development of community forestry in Nepal, Nepal J. Forest., 1, $25-33$.

Casanova, M. P. (1998), Influence of slope gradient and aspect on soil hydraulic conductivity measured with tension infiltrometer: Field study in the central zone of Chile, M.Sc. Thesis, 52 pp., Swedish University of Agricultural Sciences, Department of Soil Sciences, Uppsala, Sweden.

Chandler, D. G., and M. F. Walter (1998), Runoff responses among common land uses in the uplands of Matalom, Leyte, Philippines, Trans. ASABE, 41(6), 1635-1641.

Chappell, N. A., and J. W. Lancaster (2007), Comparison of methodological uncertainties within permeability measurements, Hydrol. Processes, 21(18), 2504-2514, doi:10.1002/hyp.6416.

Chappell, N. A., M. Sherlock, K. Bidin, R. Macdonald, Y. Najman, and G. Davies (2007), Runoff processes in Southeast Asia: Role of soil, regolith, and rock type, in Forest Environments in the Mekong River Basin, edited by H. Swada et al., pp. 3-23, Springer-Verlag, Tokyo.

Colloff, M. J., K. R. Pullen, and S. A. Cunningham (2010), Restoration of an ecosystem function to revegetation communities: The role of invertebrate macropores in enhancing soil water infiltration, Restor. Ecol., 18(1), 65-72, doi:10.1111/j.1526-100x.2010.00667.x.

Coster, C. (1938), Superficial runoff and erosion in Java, Tectona, 31, 613-728 (in Dutch, with English summary).

Cuo, L., T. W. Giambelluca, A. D. Ziegler, and M. A. Nullet (2006), Use of the distributed hydrology soil vegetation model to study road effects on hydrological processes in Pang Khum Experimental Watershed, northern Thailand, For. Ecol. Manage., 224, 81-94, doi:10.1016/j. foreco.2005.12.009

Cuo, L., T. W. Giambelluca, A. D. Ziegler, and M. A. Nullet (2008), The roles of roads and agricultural land use in altering hydrological processes in Nam Mae Rim watershed, northern Thailand, Hydrol. Processes, 22, 4339-4354, doi:10.1002/hyp.7039.

Deuchars, S. A., J. Townend, M. J. Aitkenhead, and E. A. Fitzpatrick (1999), Changes in soil structure and hydraulic properties in regenerating rain forest Soil Use Manage., 15(3), 183-187, doi:10.1111/j.1475-2743.1999.tb00086.x.

Ding, M. M., W. M. Yi, L. Y. Liao, R. Martens, and H. Insam (1992), Effect of afforestation on microbial biomass and activity in soils of tropical China, Soil Biol. Biochem., 24, 865-872, doi:10.1016/0038-0717(92) 90007-K.
Dobremez, J. F. (1976), Le Népal - Écologie et Biogéographie, 356 pp., Centre National de la Recherche Scientifique, Paris, France.

Dunne, T., and W. Dietrich (1982), Sediment sources in tropical drainage basins, in Soil Erosion and Conservation in the Tropics, ASA Special Publication No. 43, edited by S. A. El-Swaify et al., pp. 41-55, American Society of Agronomy, Soil Science Society of American, Madison, Wis.

Eckholm, E. P. (1976), Losing Ground: Environmental Stress and World Food Prospects, W.W: Norton, New York, pp. 223.

Elsenbeer, H. (2001), Hydrologic flowpaths in tropical rainforest soilscapes -A review, Hydrol. Processes, 15(10), 1751-1759, doi:10.1002/ hyp. 237

Elsenbeer, H., B. E. Newton, T. Dunne, and J. M. De Moraes (1999), Soil hydraulic conductivities of latosols under pasture, forest and teak in Rondonia, Brazil, Hydrol. Processes, 13(9), 1417-1422, doi:10.1002/ (SICI)1099-1085(19990630)13:9<1417::AID-HYP816>3.0.CO;2-6.

Gardner, R. A. M., and A. J. Gerrard (2002), Relationships between runoff and land degradation on non-cultivated land in the Middle Hills of Nepal, Int. J. Sustainable Dev. World Ecol., 9, 59-73.

Gardner, R. A. M., and A. J. Gerrard (2003), Runoff and soil erosion on cultivated rainfed terraces in the Middle Hills of Nepal, Appl. Geogr., 23 23-45, doi:10.1016/S0143-6228(02)00069-3.

Ghimire, C. P., L. A. Bruijnzeel, M. W. Lubczynski, and M. Bonell (2012), Rainfall interception by natural and planted forests in the Middle Mountains of Central Nepal, J. Hydrol., 475, 270-280, doi:10.1016/j. hydrol.2012.09.051

Ghimire, C. P., L. A. Bruijnzeel, M. Bonell, N. Coles, M. W. Lubczynski, and D. A. Gilmour (2013), The effects of sustained forest use on hillslope soil hydraulic conductivity in the Middle Mountains of Central Nepal, Ecohydrology, doi: 10.1002/eco.1367, in press.

Giambelluca, T. W. (1996), Tropical land cover change: Characterizing the postforest land surface, in Climate Change People and Policy: Developing Tropical Hemisphere Perspectives, edited by T. W. Giambelluca and A. Henderson-Sellers, pp. 293-318, John Wiley, Chichester, U.K.

Giambelluca, T. W. (2002), The hydrology of altered tropical forests, Hydrol. Processes, 16, 1665-1669, doi:10.1002/hyp.5021.

Gilmour, D. A., and M. C. Nurse (1991), Farmer initiatives in increasing tree cover in central Nepal, Mt. Res. Dev., 11(4), 329-337.

Gilmour, D. A., and R. Shah (2012), Enhancing Livelihoods and Food Security from Agroforestry and Community Forestry Systems in Nepal: Synthesis Paper, World Conservation Union (IUCN), Kathmandu, Nepal.

Gilmour, D. A., M. Bonell, and D. S. Cassells (1987), The effects of forestation on soil hydraulic properties in the Middle Hills of Nepal: A preliminary assessment, Mt. Res. Dev., 7(3), 239-249.

Godsey, S., and H. Elsenbeer (2002), The soil hydrologic response to forest regrowth: A case study from southwestern Amazonia, Hydrol. Processes, 16(7), 1519-1522, doi:10.1002/hyp.605.

Hairiah, K., H. Sulistyani, D. Suprayogo, P. Widianto Purnomosidhi, R. Harto Widodo, and M. Van Noordwijk (2006), Litter layer residence time in forest and coffee agroforestry systems in Sumberjaya, West Lampung, For. Ecol. Manage., 224, 45-57, doi:10.1016/j.foreco.2005.12.007.

Hall, R. L., and I. R. Calder (1993), Drop size modification by forest canopies: Measurements using a disdrometer, J. Geophys. Res., 90, 18,465-18,470, doi:10.1029/93JD01498.

Hamza, M. A., and W. K. Anderson (2005), Soil compaction in cropping systems: A review of the nature, causes and possible solutions, Soil Tillage Res., 82, 121-145, doi:10.1016/j.still.2004.08.009.

Hassler, S. K., B. Zimmermann, M. Van Breugel, J. S. Hall, and H. Elsenbeer (2011), Recovery of saturated hydraulic conductivity under secondary succession on former pasture in the humid tropics, For. Ecol. Manage., 261(10), 1634-1642, doi:10.1016/j.foreco.2010.06.031.

Hofer, T. (1993), Himalayan deforestation, changing river discharge, and increasing floods: Myth or reality?, Mt. Res. Dev., 13(3), 213-233.

Hofer, T., and B. Messerli (2006), Floods in Bangladesh. History, Dynamics and Rethinking the Role of the Himalayas, $450 \mathrm{pp}$., United Nations University Press, Tokyo, and United Nations Food and Agriculture Organization, Rome. Hölscher, D., J. M. Roberts, and J. Mackensen (2005), Forest recovery in the humid tropics: Changes in vegetation structure, nutrient pools and the hydrological cycle, in Forests, Water and People in the Humid Tropics, edited by M. Bonell and L. A. Bruijnzeel, pp. 598-621, Cambridge Univ. Press, Cambridge, U. K.

Hrabovsky, J. P., and K. Miyan (1987), Population growth and land use in Nepal. "The great turnabout", Mt. Res. Dev., 7, 264-270.

HURDEC Nepal, and M. Hobley (2012), Community Forestry Impact Study: Persistence and Change, Review of 30 Years of Community Forestry in Nepal, HURDEC, Kathmandu, Nepal.

Ilstedt, U., A. Malmer, E. Verbeeten, and D. Murdiyarso (2007), The effect of afforestation on water infiltration in the tropics: A systematic review and meta-analysis, For. Ecol. Manage., 251(1-2), 45-51, doi:10.1016/j. foreco.2007.06.014 
Impat, P. (1981), Hydrometeorology and sediment data for Phewa Watershed: 1979 data, in Phewa Tal Technical Report no. 15, 29 pp., Integrated Watershed Management Project, Department of Soil Conservation and Watershed Management, Kathmandu.

Ives, D. J., and B. Messerli (1989), The Himalayan Dilemma - Reconciling Development and Conservation, Routledge, London.

Jackson, R. B., E. G. Jobbagy, R. Avissar, S. B. Roy, D. J. Barrett, C. W. Cook, K. A. Farley, D. C. Le Maître, B. A. McCarl, and B. C. Murray (2005), Trading water for carbon with biological carbon sequestration, Science, 310, 1944-1947, doi:10.1126/science.1119282.

Joel, A., and I. Messing (2000), Application of two methods to determine hydraulic conductivity with disc permeameters on sloping land, Eur. J. Soil Sci., 51, 93-98, doi:10.1046/j.1365-2389.2000.00281.x.

Joshi, G., and G. C. S. Negi (2011), Quantification and valuation of forest ecosystem services in the western Himalayan region of India, Int. J. Biodivers. Sci. Ecosyst. Services Manage., 7(1), 2-11, doi:10.1080/ 21513732.2011.598134.

Konert, M., and J. Vandenberghe (1997), Comparison of layer grain size analysis with pipette and sieve analysis: A solution for the underestimation of the clay fraction, Sedimentology, 4, 523-535, doi:10.1046/j.13653091.1997.d01-38.x.

Krishnaswamy, J., M. Bonell, B. Venkatesh, B. K. Purandara, S. Lele, M. C. Kiran, V. Reddy, S. Badiger, and K. N. Rakesh (2012), The rainrunoff response of tropical humid forest ecosystems to use and reforestation in the Western Ghats of India, J. Hydrol., 472-473, 216-237, doi:10.1016/j.jhydrol.2012.09.016.

Krishnaswamy, J., M. Bonell, B. Venkatesh, B. K. Purandara, K. N. Rakesh, S. Lele, M. C. Kiran, V. Reddy, and S. Badiger (2013), The groundwater recharge response and hydrologic services of tropical humid forest ecosystems to use and reforestation: Support for the "infiltrationevapotranspiration trade-off hypothesis", J. Hydrol., 498, 191-209, doi:10.1016/j.jhydrol.2013.06.034.

Kruskal, W. H., and W. A. Wallis (1952), Use of ranks in one-direction variance analysis, J. Am. Stat. Assoc., 47, 583-621.

Lal, R. (1988), Effects of macrofauna on soil properties in tropical ecosystems, Agric. Ecosyst. Environ., 24, 101-116, doi:10.1016/0167-8809(88) 90059-X.

Lamichhane, B. R., and K. Awasthi (2009), Changing climate in a mountain sub-watershed in Nepal, J. For. Livelihood, 8(1), 100-106.

Lebron, I., D. A. Robinson, M. Oatham, and M. N. Wuddivira (2012), Soil water repellency and $\mathrm{pH}$ soil change under tropical pine plantations compared with native forest, J. Hydrol., 414-415, 194-200, doi:10.1016/ jhydrol.2011.10.031

Maharjan, P. L. (1991), The soil survey of the Jikhu Khola catchment, in Soil Fertility and Erosion Issues in the Middle Mountains of Nepal, edited by P. B. Shah, et al., pp. 195-200, Topographical Survey Branch, Kathmandu, and University of British Columbia, Vancouver.

Mahat, T. B. S., D. M. Griffin, and K. R. Shepherd (1986), Human impact on some forests of the Middle Hills of Nepal. Part 2. Some major human impacts before 1950 on the forests of Sindhu Palchok and Kabhre Palanchok, Mt. Res. Dev., 6(4), 325-334.

Mahat, T. B. S., D. M. Griffin, and K. R. Shepherd (1987), Human impacts on some forests of the Middle Hills of Nepal. Part 3. Forests in the subsistence economy of Sindhu Palchok and Kabhre Palanchok, Mt. Res. Dev., 7(1), 53-70.

Mapa, R. B. (1995), Effect of reforestation using Tectona grandis on infiltration and soil water retention, For. Ecol. Manage., 77, 119-125, doi:10.1016/0378-1127(95)03573-S.

Martinez, L. J., and J. A. Zinck (2004), Temporal variation of soil compaction and deterioration of soil quality in pasture areas of Colombian Amazonia, Soil Tillage Res., 75(1), 3-17, doi:10.1016/j.still.2002.12.001.

Matheron, G. (1962), Traité de Géostatistique Appliqué, Tôme 1, Memoires du Bureau de Recherches Géologiques et Minières, Paris.

McIntyre, D. S. (1958a), Permeability measurements of soil crusts formed by raindrop impact, Soil Sci., 85, 185-189, doi:10.1097/00010694195804000-00002.

McIntyre, D. S. (1958b), Soil splash and the formation of surface crusts by raindrop impact, Soil Sci., 85, 261-266.

McKenzie, N. J., H. P. Cresswell, and T. W. Green (2002), Field measurement of unsaturated hydraulic conductivity using tension infiltrometers, in Soil Physical Measurement and Interpretation for Land Evaluation, edited by N. J. Mckenzie et al., pp. 119-130, CSIRO Publishing, Melbourne.

Merz, J. (2004), Water balances, floods and sediment transport in the Hindu Kush-Himalayas, 339 pp., PhD thesis, University of Bern, Bern, Switzerland.

Merz, J., G. Nakarmi, S. K. Shrestha, B. M. Dahal, P. M. Dangol, M. P. Dhakal, B. S. Dongol, S. Sharma, P. B. Shah, and R. Weingartner (2003), Water: A scarce resource in rural watersheds of Nepal's Middle Mountains, Mt. Res. Dev., 23(1), 41-49.
Mishra, B. K., and S. Herath (2011), Climate projections downscaling and impact assessment on precipitation over upper Bagmati river basin, Nepal, Paper presented at the Third International Conference on Addressing Climate Change for Sustainable Development through Upscaling Renewable Energy Technologies, Kathmandu, Nepal.

Mohanty, B. P., and Z. Mousli (2000), Saturated hydraulic conductivity and soil water retention properties across a soil-slope transition, Water Resour. Res., 36, 3311-3324, doi:10.1029/2000WR900216.

Molina, A., G. Govers, V. Vanacker, J. Poesen, E. Zeelmaekers, and F. Cisneros (2007), Runoff generation in a degraded Andean ecosystem: Interaction of vegetation cover and land use, Catena, 71, 357-370, doi:10.1016/j.catena.2007.04.002

Muñoz-Villers, L. E., F. Holwerda, M. Gomez-Cardenas, M. Equihua, H. Asbjornsen, L. A. Bruijnzeel, B. E. Marin-Castro, and C. Tobon (2012), Water balances of old-growth and regenerating montane cloud forests in central Veracruz, Mexico, J. Hydrol., 462-463, 53-66, doi:10.1016/j. jhydrol.2011.01.062.

Myers, N. (1986), Environmental repercussions of deforestation in the Himalayas, J. World For. Resour. Manage., 2, 63-72.

Nautiyal, J. C., and P. S. Babor (1985), Forestry in the Himalayas-How to avert an environmental disaster, Interdisciplinary Sci. Rev., 10, 27-41.

Negi, G. C. S., V. Joshi, and K. Kumar (1998), Spring sanctuary development to meet household water demand in the mountains: A call for action, in Research for Mountain Development: Some Initiatives and Accomplishments, pp. 25-48, Gyanodaya Prakashan, Nainital, India.

Negishi, J. N., R. C. Sidle, S. Noguchi, A. R. Nik, and R. Stanforth (2006), Ecological roles of roadside fern (Dicranopteris curranii) on logging road recovery in Peninsular Malaysia: Preliminary results, For. Ecol. Manage., 224(1-2), 176-186, doi:10.1016/j.foreco.2005.12.017.

Pathak, P. C., A. N. Pandey, and J. S. Singh (1984), Overland flow, sediment output and nutrient loss from certain forested sites in the central Himalaya, India, J. Hydrol., 71(3-4), 239-251, doi:10.1016/0022-1694(84)90099-4.

Patnaik, N., and S. S. Virdi (1962), Field infiltration studies in Doon Valley, Irrig. Power, 19, 1003-1012.

Paudel, K. P., D. Dahal, and R. Shah (2012), Abandoned Agricultural Land in Mid Hills of Nepal: Status, Causes and Consequences, 42 pp., World Conservation Union (IUCN Nepal), Kathmandu, Nepal.

Perroux, K. M., and I. White (1988), Designs for disc permeameters, Soil Sci. Soc. Am. J., 52(5), 1205-1215, doi:10.2136/sssaj1988.03615995005200050001x.

Purwanto, E. (1999), Erosion, sediment delivery and soil conservation in an upland agricultural catchment in West Java, Indonesia, $\mathrm{PhD}$ thesis, 219 pp., Vrije Universiteit, Amsterdam.

$\mathrm{R}$ Development Core Team (2008), R: A Language and Environment for Statistical Computing, R Foundation for Statistical Computing, Vienna, Austria.

República (2012), Locals blame pine trees for declining water sources, República, IV(202), 19 November. [Available at www.myrepublica.com.]

Reynolds, W. D., D. E. Elrick, and G. C. Topp (1983), A reexamination of the constant head well permeameter method for measuring saturated hydraulic conductivity above the water table, Soil Sci., 136(4), 250-268.

Rijsdijk, A., and L. A. Bruijnzeel (1991), Erosion, sediment yield and land-use patterns in the upper Konto watershed, East Java, Indonesia. Part III: Results of the 1987 - 1989 measuring campaign, Project Communication 18, Konto River Project, Kingdom of the Netherlands, Ministry of Foreign Affairs, Directorate General of International Cooperation, $58 \mathrm{pp}$.

Rijsdijk, A., L. A. Bruijnzeel, and C. Kukuh Sutoto (2007), Runoff and sediment yield from rural roads, trails and settlements in the upper Konto catchment, East Java, Indonesia, Geomorphology, 87, 28-37, doi:10.1016/j.geomorph.2006.06.040.

Schreier, H., S. Brown, and J. R. MacDonald (Eds.) (2006), Too Little and Too Much: Water and Development in a Himalayan Watershed, 258 pp., Institute for Resources and Environment, University of British Columbia, Canada.

Scott, D. F., L. A. Bruijnzeel, and J. Macksensen (2005), The hydrological and soil impacts of forestation in the tropics, in Forest, Water and People in the Humid Tropics, edited by M. Bonell and L. A. Bruijnzeel, pp. 622-650, Cambridge Univ. Press, Cambridge, U.K

Shapiro, S. S., and M. B. Wilk (1965), An analysis of variance test for normality (complete samples), Biometrika, 52(34), 591-611.

Shepherd, K. R., and D. M. Griffin (1984), The Nepal-Australia Forestry Project: A case study of research and development, in Technology Transfer in Forestry, Forestry Commission Bulletin no. 61, pp. 16-23, London.

Singh, J. S., and S. P. Singh (1992), Forests of Himalaya: Structure, Functioning and Impact of Man, 294 pp., Gyanodaya Prakashan, Nainital, India.

Singh, J. S., U. Pandey, and A. K. Tiwari (1984), Man and forests: A central Himalayan case study, Ambio, 13, 80-87.

Singh, N., and R. C. Sundriyal (2009), Fuelwood, fodder consumption and deficit pattern in central Himalayan village, Nat. Sci., 7(4), 85-88. 
GHIMIRE ET AL.: REFORESTATION AND HILLSLOPE $K_{\mathrm{fs}}$

Singh, S. P. (2007), Himalayan Forest Ecosystem Services, Central Himalayan Environment Association, Nainital, India

Talsma, T., and P. M. Hallam (1980), Hydraulic conductivity measurement of forest catchments, Aust. J. Soil Res., 18(2), 139-148.

Tambe, S., G. Kharel, M. L. Arrawatia, H. Kulkarni, K. Mahamuni, and A. K. Ganeriwala (2012), Reviving dying springs: Climate change adaptation experiments from the Sikkim Himalaya, Mt. Res. Dev., 32(1), $62-72$.

Tiwari, K. R., B. K. Sitaula, R. M. Bajracharya, and T. Børresen (2009), Runoff and soil loss responses to rainfall, land use, terracing and management practices in the Middle Mountains of Nepal, Acta Agric. Scand., Sect. B Soil Plant Sci., 59(3), 197-207, doi:10.1080/09064710802006021.

Tiwari, P. C. (1995), Natural Resources and Sustainable Development in Himalaya, 245 pp., Shree Almora Book Depot, Almora, India.

Tobón, C., L. A. Bruijnzeel, K. F. A. Frumau, and J. C. Calvo-Alvarado (2010), Change in soil physical properties after conversion of tropical montane cloud forest to pasture in northern Costa Rica, in Tropical Montane Cloud Forests: Science for Conservation and Management, edited by L. A. Bruijnzeel et al., pp. 502-515, Cambridge Univ. Press, Cambridge, U. K.

Tomasella, J., and M. G. Hodnett (1996), Soil hydraulic properties and van Genuchten parameters for an oxisol under pasture in central Amazonia, in Amazonia Deforestation and Climate, edited by J. H. C. Gash et al., pp. 101-124, J. Wiley, Chichester, U. K.

Trimble, S. W., F. H. Weirich, and B. L. Hoag (1987), Reforestation and the reduction of water yield on the Southern Piedmont since circa 1940, Water Resour. Res., 23, 425-437, doi:10.1029/WR023i003p00425.

Tsukamoto, Y. (1975), Effect of forest litters on runoff cycle in a small experimental watershed, IAHS Publ., 117, 487-495.

Turkelboom, F., J. Poesen, and G. Trébuil (2008), The multiple land degradation effects caused by land-use intensification in tropical steeplands: A catchment study from northern Thailand, Catena, 75, 102-116, doi:10.1016/j. catena.2008.04.012.

Van Dijk, A. I. J. M. (2002), Water and sediment dynamics in bench-terraced Agricultural steeplands in West Java, Indonesia, PhD thesis, 362 pp., Vrije Universiteit, Amsterdam.

Vigiak, O., S. J. E. van Dijck, E. E. van Loon, and L. Stroosnijder (2006), Matching hydrologic response to measured effective hydraulic conductivity, Hydrol. Processes, 20, 487-504, doi:10.1002/hyp.5916.

Walkley, A., and I. A. Black (1934), An examination of the Degtjareff method for determining soil organic matter and a proposed modification of the chromic acid titration method, Soil Sci., 37, 29-37.

Waterloo, M. J. (1994), Water and nutrient dynamics of Pinus caribaea plantation forests on former grassland soils in Southwest Viti Levu, Fiji, $\mathrm{PhD}$ thesis, 478 pp., Vrije Universiteit, Amsterdam.

Waterloo, M. J., L. A. Bruijnzeel, H. F. Vugts, and T. T. Rawaqa (2000), Evaporation from Pinus caribaea plantations on former grassland soils under maritime tropical conditions, Water Resour. Res., 35, 2133-2144, doi:10.1029/1999WR900006.

Webb, A. A., M. Bonell, L. Bren, P. N. J. Lane, D. McGuire, D. G. Neary, J. Nettles, D. F. Scott, J. John Stednick, and Y. Wang (Eds.) (2012), Revisiting Experimental Catchment Studies in Forest Hydrology, Proceedings of a Workshop held in Melbourne, 2011, IAHS Publ., vol. 353, 240 pp., IAHS, Wallingford.
Webster, R., and M. A. Oliver (2007), Geostatistics for Environmental Scientists, 315 pp., J. Wiley, Chichester, U. K.

Wester, R. G. C. (2013), Feasibility of assessing water scarcity with 3R techniques, in the Salyan district in the Middle Mountains of western Nepal, M.Sc. Thesis, 148 pp., VU University, Amsterdam, The Netherlands.

Wiersum, K. F. (1984), Surface erosion under various tropical agroforestry systems, in Effects of Forest Land Use on Erosion and Slope Stability, edited by C. L. O'Loughlin, and A. J. Pearce, pp. 231-239, IUFRO, Vienna, and East-West Center, Honolulu, Hawaii.

Wiersum, K. F. (1985), Effects of various vegetation layers in an Acacia auriculiformis forest plantation on surface erosion in Java, Indonesia, in Soil Erosion and Conservation, edited by S. El-Swaify et al., pp. 79-89, Soil Conservation Society of America, Ankeny, Wisconsin.

Wilcox, B. P., and Y. Huang (2010), Woody plant encroachment paradox: Rivers rebound as degraded grasslands convert to woodlands, Geophys. Res. Lett., 37, L07402, doi:10.1029/2009GL041929.

Zhou, G. Y., J. D. Morris, J. H. Yan, Z. Y. Yu, and S. L. Peng (2002), Hydrological impacts of reafforestation with eucalypts and indigenous species: A case study in southern China, For. Ecol. Manage., 16, 209-222, doi:10.1016/S0378-1127(01)00694-6.

Zhou, G., X. Wei, Y. Luo, M. Zhang, Y. Li, Y. Qiao, H. Liu, and C. Wang (2010), Forest recovery and river discharge at the regional scale of Guangdong Province, China, Water Resour. Res., 46, W09503, doi:10.1029/2009WR008829.

Ziegler, A. D., and T. W. Giambelluca (1997), Importance of rural roads as source areas for runoff in mountainous areas of northern Thailand, $J$. Hydrol., 196, 204-229.

Ziegler, A. D., T. W. Giambelluca, R. A. Sutherland, M. A. Nullet, Y. Yarnasarn, J. Pinthong, P. Preechapanya, and S. Jaiaree (2004a) Toward understanding the cumulative impacts of roads in upland agricultural watersheds of northern Thailand, Agric. Ecosyst. Environ., 104, 145-158, doi:10.1016/j.agee.2004.01.012.

Ziegler, A. D., T. W. Giambelluca, L. T. Tran, T. T. Vana, M. A. Nullet, J. Fox, T. D. Vien, J. Pinthong, J. F. Maxwell, and S. Evett (2004b), Hydrological consequences of landscape fragmentation in mountainous northern Vietnam: Evidence of accelerated overland flow generation, J. Hydrol., 287, 124-146, doi:10.1016/j.jhydrol.2003.09.027.

Ziegler, A. D., J. N. Negishi, R. C. Sidle, S. Noguchi, and A. R. Nik (2006), Impacts of logging disturbance on hillslope saturated hydraulic conductivity in a tropical forest in Peninsular Malaysia, Catena, 67, 89-104, doi:10.1016/j.catena.2006.02.008.

Zimmermann, B., and H. Elsenbeer (2008), Spatial and temporal variability of soil saturated hydraulic conductivity in gradients of disturbance, J. Hydrol., 361, 78-95, doi:10.1016/j.jhydrol.2008.07.027.

Zimmermann, B., and H. Elsenbeer (2009), The near-surface hydrological consequences of disturbance and recovery: A simulation study, J. Hydrol., 364, 115-127, doi:10.1016/j.jhydrol.2008.10.016.

Zimmermann, B., H. Elsenbeer, and J. M. De Moraes (2006), The influence of land-use changes on soil hydraulic properties: Implications for runoff generation, For. Ecol. Manage., 222, 29-38, doi:10.1016/j.foreco.2005.10.070.

Zimmermann, B., A. Papritz, and H. Elsenbeer (2010), Asymmetric response to disturbance and recovery: Changes of soil permeability under forestpasture-forest transitions, Geoderma, 159, 209-215, doi:10.1016/j. geoderma.2010.07.013 